\title{
O Dilema da Psicologia Contemporânea
}

Paulo da Silveira Rosas

ÍNDICE

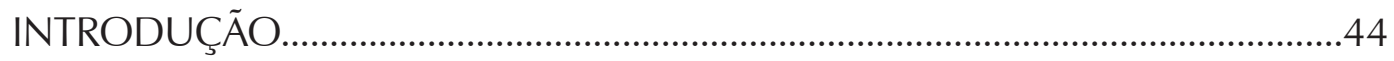

CAPÍTULO I - Da introspecção, como método original da psicologia...................45

CAPÍTULO II - O legado da psiquiatria tradicional....................................................50

CAPÍTULO III - Onde se fala das incertezas da introspecção e das vissitudes da observação objetiva......................................................................79

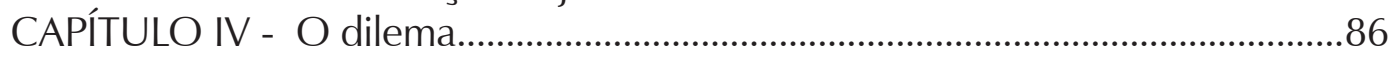

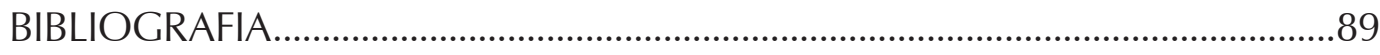


"Man sees more of the things themselves when he sees more of their origin; for their origin is a part of them and indeed the most important part of them". 


\section{O Dilema da Psicologia Contemporânea}

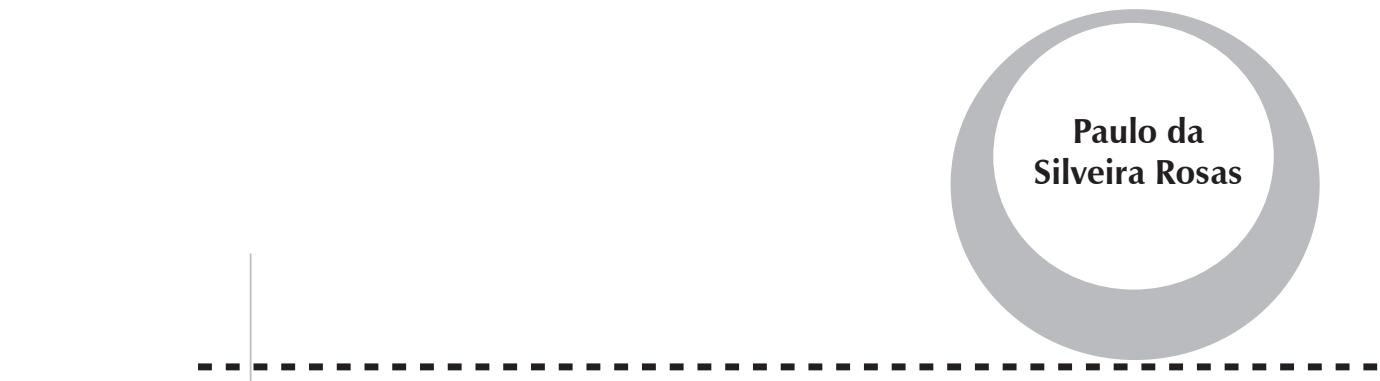

INTRODUÇÃO

Assumir com legitimidade um lugar entre as ciências vem sendo uma persistente pretensão da psicologia, desde, pelo menos, o movimento de Wundt, em Leipzig, ou talvez a proposta psicofísica de Fechner. Muito esforço vem sendo gasto neste sentido. Entretanto, os frutos alcançados não sabem a grande êxito.

De outra parte, ignorando ou em conflito com os achados da psicologia dita científica, vê-se no século XX um crescente sucesso da psicologia aplicada, não apenas nos domínios da clínica ou dos testes, mais conhecidos do público leigo, como nos mais diversos campos da atividade humana. Seria esta uma advertência de dever a psicologia aterse ao domínio mágico da intuição e do casuísmo e abandonar uma batalha inglória? $\mathrm{Ou}$, pelo contrário, o erro básico não estaria na escolha do modelo científico que parece perseguido pelos psicólogos, predo- 
minantemente positivista, à maneira da física e das ciências naturais? Certo, como ciência, a psicologia tem sido quase sempre encarada como uma ciência natural. Mas, pensando sem preconceitos, a psicologia é uma ciência natural?

Este ensaio é um parecer sobre o problema. A rigor, para ser o assunto equacionado em toda sua extensão, deveria abordar as diversas áreas da intervenção psicológica: social, escolar, industrial, clínica. E talvez mesmo os campos específicos de estudo da psicologia acadêmica.

Nos limites do que pretendo desenvolver - um parecer sobre um assunto que penso ser de transcendental importância para o futuro do projeto psicológico - , considerei desnecessário e inútil assim agir. Tomei como referencial básico a psicologia acadêmica - nos termos das focalizações metodológicas dos grandes sistemas - e escolhi em contraposição a psicologia clínica, sua herança psiquiátrica e suas colocações implícitas em face do método científico.

Assumo uma atitude crítica. Mas, em nenhum momento alimento qualquer dúvida quanto aos seguintes pontos:

— em primeiro lugar, a psicologia é necessária;

— em segundo lugar, por sua reflexão, por sua inventividade, os psicólogos encontrarão o caminho adequado para a realização de seu programa;

— finalmente, nada do que foi feito, nada do que foi até o momento tentado, nem mesmo as hipóteses paracientíficas, são inúteis enquanto aproximações, quando nada por deixarem claro conduzirem a caminhos sem saída.

\section{CAPÍTULO I}

\section{Da introspecção, como método original da psicologia}

No princípio era a filosofia. No princípio era a especulação. Mas, enquanto psicólogo, o filósofo especulava "voltado para dentro" e em torno de si mesmo. De suas experiências. De seu modo de se perceber e de perceber os outros. De perceber o cosmo. Os apotegmas dos "sete sábios" — ou dezessete, pouco importa —, talvez manipulados pela tradição de que foram recolhidos, são conselhos e reflexões ditados pela "experiência" e a partir de um dobrar-se sobre si mesmo. De uma "introspecção".

Comportamento que em Sócrates se fez método, hábil método de persuasão. Pois a maiêutica é o caminho pelo qual Sócrates especula ou dirige a especulação, centrado sobre o tema e talvez orientado pelas idéias previamente elaboradas. O "conhece-te a ti mesmo", de Quílon e do oráculo de Delfos, em Sócrates fez-se lema. É um profundo convite à introspecção.

Muitos responderam a este convite. Os de seu tempo, antes de tudo. E outros, no curso da história, à maneira do Cícero dos Tusculanes, do Boécio da Consolação da Filosofia, do Santo 
Agostinho das Confissões e dos Solilóquios — todos eles exímios na arte de mergulharem dentro de mesmos e de lá trazerem um pensamento sobre o comportamento do homem.

Contudo, não se pode dizer que a introspecção então existisse como método da psicologia. Nas palavras de Dwelshauvers (1930, pp. 45-46), até o século XVI o emprego da introspecção foi muito reduzido, somente sendo introduzido na psicologia "graças ao estudo detalhístico que os moralistas, do Renascimento à Revolução, consagraram às paixões". E Dwelshauvers menciona de modo específico Montaighe, Bourdaloue, La Bruyère e Vauvernagues.

Com Descartes é que a introspecção assumiu um papel definido como método da psicologia. O dualismo cartesiano admitia a existência de corpo e alma na composição do homem. O corpo seria semelhante a uma máquina, submetendo-se assim ás leis da mecânica, devendo ser estudado pelo método das ciências naturais. Enquanto a alma, possuidora de "res cogitans", não poderia ser regida por leis determinísticas e deveria ser estudada pela introspecção. Para Descartes, o corpo tem um papel mediador (Dioptrique, 1952; Les Passions de L'âme, 1948, pp. 480-481). Só a alma percebe: os movimentos dos membros procedem do corpo e os pensamentos, da alma.

Quadro 1

Apotegmas dos Sete Sábios (Grécia, séculos VI - V a.C.)

1- De Cleóbulo de Lindos

"Mostremos ouvir, mas saibamos distinguir".

2 - De Sólon de Atenas

"Nunca digas tudo o que sabes".

3 - De Pitaco de Mitilene

"Não reveles projetos para, se falhares, não seres motivo de troça".

4 - De Tales de Mileto

"A maior alegria vem da posse do objeto amado".

5 - De Bias de Priene

"Aprende a saber ouvir".

6 - De Periandro de Corinto

"Oculta os desgostos, para não dares motivo de gozo aos inimigos".

7 - De Quílon de Lacedemônia

"Conhece-te a ti mesmo".

Fonte: Pinharanda Gomes, Filosofia Grega Pré-Socrática. Guimarães \& Cia. Editores, Lisboa, 1973.

Muitos especularam sobre o comportamento do homem a partir de uma reflexão sobre sua própria experiência, como aconteceu com Spinoza, Pascal e, em um outro nível, La Rochefoucauld e Vauvernagues. Entretanto, seria com Maine de Biran, o angustiado e ambivalente Maine de Biran, dividido entre o desejo expresso de contemplação e uma vida ativa de político, que a introspecção seria elevada à condição de método por excelência da psicologia. Definida como "ciência dos fatos interiores", a psicologia elaborada por Maine de Biran objetiva a "de- 
*Mais tarde Ernst Mach (1908, p. 18) proporia a distinção que se fez clássica: físico é o que é dado imediatamente a todos, enquanto psíquico é o que é dado imediatamente apenas a um indivíduo e para os outros só é conhecido por analogia. composição" da "faculdade de pensar", de modo a esclarecer as "faculdades elementares" (Maine de Biran, 1942; La Valette Mombrun, 1914). Maine de Biran não pode ser considerado um psicólogo, no sentido moderno do termo, mas foi um dos mestres na arte da introspecção como outros já citados - um "metafísico que mergulhava nos subterrâneos da alma" (Gouhier, 1948; B. Halda, 1970), lúcido, um dos mais lúcidos de toda a história da "protopsicologia".

\section{Wundt}

A hipótese de ser a introspecção o método psicológico por excelência foi reforçada pela "nova psicologia", a partir de Wilhelm Wundt. Para Wundt a psicologia é o estudo da experiência imediata. Situada em "um lugar intermediário entre as ciências naturais e as ciências morais" (1886, I, p. 4), a psicologia deveria ater-se à análise dos "elementos" dos processos ou "conteúdos mentais" (sensações, imagens, sentimentos), à descrição do modo pelo qual esses elementos se conectariam e à descoberta das leis de sua conexão.

Pensava ele que a consciência seria formada por um número finito de elementos sensoriais irredutíveis, de modo que a descoberta de suas combinações e relações e das "leis que governam essas combinações e relações" preencheria toda a problemática da psicologia (Wundt, 1912, p. 1; Beloff, 1975, p. 62).

De acordo com o pensamento de Wundt, a psicologia pode e deve ser experimental. A chave para a investigação da consciência é a "experiência imediata". E o estudo da experiência imediata deveria ser feito por meio da introspecção $(*)$.

Contudo, há uma notável diferença entre o conceito de introspecção até então pensado, de livre exercício de refletir o mundo e o homem sobre a vida interior, à Maine de Biran, e a proposta wundtiana de uma "auto-observação" que pretende ser controlada. A primeira parecia-Ihe inútil para os fins da ciência (cf. Marx e Hillix, 1967, p. 78). A segunda entendia ser um método de pesquisa psicológica cientificamente aceitável.

É possível que o trabalho de Wundt tenha terminado por ser uma tentativa abortada de construir uma psicologia pura, como pretende John Beloff (1975, p. 41). Mas, não há como negar que sua atitude emprestou à introspecção um novo status.

\section{Titchener}

Titchener, principal intérprete do pensamento de Wundt nos Estados Unidos da América, na verdade construtor de um estruturalismo à imagem de Wundt, mantinha como principal meta da psicologia o estudo da experiência imediata através da análise de seus elementos mais simples, da descoberta de suas combinações e da conexão com suas condições fisiológicas. A experiência imediata de um indivíduo em um momento dado compreende o que ele entende por consciência. A rigor, admite (1922, p. 18) com evidente sabor heraclitiano, não podemos observar duas vezes a mesma consciência: "a corrente do espírito corre sempre e jamais retorna... "Embora a "maré alta de ontem jamais volte, como não voltará nossa consciência de ontem", a ciência psicológica é possível porque podemos observar a "consciência particular" e os "processos mentais se agrupam da mesma maneira, mostram o mesmo tipo de arranjo, sempre que o organismo é colocado nas mesmas circunstâncias". 
O método da psicologia, pensa Titchener, é o mesmo método das demais ciências - a observação. Entretanto (1922, p. 19), enquanto a observação nas ciências físicas é extrospecção, pois é voltada para fora, a observação psicológica é introspecção, pois é voltada para dentro. Titchener dá exemplos de situações diversas, mais ou menos complexas, em que a introspecção é o método utilizado para a coleta das informações.

Embora aceite que a decomposição da consciência possa dificultar a compreensão de "certas ligações intermediárias", supõe que tal obstáculo será insignificante, desde que se aplique a "retrospecção" e se compare os resultados atuais, parciais, com "a lembrança da experiência global". A psicologia para Titchener é uma ciência pura, não comportando qualquer tipo de aplicação, seja clínica, seja psicométrica ou outra qualquer (cf. Heidbreder, 1933, pp. 113 e ss.).

\section{Brentano}

De outra parte, no mesmo ano, 1874, em que Wilhelm Wundt publicava o segundo volume da primeira edição de sua Psicologia Fisiológica, Franz Brentano trazia à luz, em Leipzig, uma obra que marcaria a história da psicologia de modo igualmente crucial: a Psicologia do ponto de vista empírico.

Brentano (1944) contraditava o elementarismo de Wundt, propondo um modelo fenomenológico para a psicologia - a psicologia do ato. Nega a hipótese da psicologia como ciência natural (1944, p. 32) e em particular a clássica distinção cartesiana: "nem a ciência da natureza pode ser definida como a ciência dos corpos, nem a psicologia, como a ciência da alma; simplesmente será preciso considerar a primeira como a ciência dos fenômenos físicos e a segunda, como a ciência dos fenômenos psíquicos". Prossegue citando F. A. Lange (História do Materialismo), cujo pensamento endossa, sobre a necessidade de se construir uma "psicologia sem alma".

A primeira tarefa do psicólogo, pensa Brentano (1944, pp. 62 e ss.), consiste em "determinar de maneira certa as características comuns a todos os fenômenos psíquicos". E, a partir daí, reunir os fenômenos psíquicos em classes fundamentais, conforme as exigências de suas "afinidades naturais" - tarefas que ele próprio tentaria cumprir, abordando-as não apenas na Psicologia de 1874 mas, sobretudo, em apêndice àquele ensaio, Sobre a Classificação dos Fenômenos Psíquicos, publicado em Leipzig em 1911.

Para desempenhar tais tarefas, vale dizer, para realizar os estudo dos fenômenos psíquicos, compreendidos como "atos", o psicólogo deveria,, na concepção de Brentano, utilizar a introspecção (1944, pp. 48 e ss.). Todavia, longe de a aceitar como "observação interna", o que Ihe parece impossível, concebe-a como "percepção interior", "fonte primeira e indispensável da psicologia".

Reconhece ser isto uma limitação da psicologia — única ciência para a qual a observação direta seria inaplicável. Entretanto, essa limitação pode ser até certo ponto compensada pelo "conhecimento indireto" dos fenômenos psíquicos de outros indivíduos, uma vez que os mesmos se manifestam externamente (1944, pp. 56-57): os estados psíquicos podem, "mesmo sem a intervenção da palavra, se manifestar externamente, de modo menos perfeito, é verdade, mas não raro com suficiente clareza". Mencionando Feuchtersleben, sugere ser preciso prender-se menos ao que as pessoas dizem do que ao que deixam involuntariamente entrever. $\mathrm{E}$, partindo do exemplo apresentado por Darwin (em A Expressão das Emoções no Homem e no Animal, 
obra publicada em 1872), defende que o fenômeno físico observado, isto é, o "ato", "pode servir de indicador em relação ao fenômeno psíquico invisível" (não cita, mas poderia ter citado Anaxágoras, século V a. C, para quem "o visível abre nossos olhos para o invisível"). Parece-lhe, não obstante, ser evidente que "tais sinais não são a coisa" e, por conseguinte, seria tão ingênuo falar-se de observação interna subjetiva quanto pretensioso, de observação externa objetiva.

Entende ainda Brentano que a observação de fatos físicos, atos, indicadores indiretos de fenômenos psíquicos, possibilitaria inferir "os estados de uma vida psíquica mais simples do que a nossa" (crianças, cegos de nascimento, animais), assim como de "estados psíquicos mórbidos".

\section{Reflexões em torno de uma conclusão provisória}

Apesar de representarem diferentes modelos, um, elementarista, o de Wundt e Titchener, outro, fenomenológico, o de Bretano, legaram ambos à "nova psicologia" nascente a herança de uma metodologia subjetiva, inevitavelmente subjetiva, incômoda herança havia séculos repassada e que punha em questão todo o projeto científico da psicologia. Pois, à luz do positivismo dominante no início do século XX, pelo menos no tocante à concepção de ciência, pouco importaria a engenhosidade dos experimentalistas, se as informações disponíveis não tivessem a chancela do objetivo.

Aceita por ambas as correntes originais do pensamento psicológico - a estruturalista e a fenomenológica —, a introspecção se generalizou como o método oficial da psicologia acadêmica do século XIX, apesar das muitas divergências registradas entre as diversas correntes de pensamento.

Se assim acontecia com a psicologia de orientação germânica, igualmente acontecia com a psicologia norte-americana dos primeiros tempos. Em 1891 William James publicava a primeira edição de seus Princípios de Psicologia, onde contestava as posições de Wundt e Bretano quanto à natureza da psicologia - para ele a psicologia deveria ser classificada como uma ciência natural. Aproxima-se, no entanto, de ambos, enquanto define a psicologia como o estudo da vida mental, "tanto de seus fenômenos quanto de suas condições". Aproxima-se, ainda, enquanto sustenta que a introspecção é "tudo o que podemos contar, antes de tudo e sempre". Mas reconhece suas limitações científicas, entre outras "fontes de erro em psicologia", quais sejam a "influência corruptora da linguagem" e a "falácia do psicólogo" (1955, pp. 120-129).

Na realidade, a insuficiência da introspecção é sentida pela maioria dos psicólogos que a aplicam. Apesar disso, até o advento do Behaviorismo é geralmente aceita e defendida nos manuais clássicos, como o de Hoffding, publicado pela primeira vez em 1882 (1909, pp. 21 e ss.). E será ainda mantida, mesmo após o Behaviorismo, presente em manuais de tendência conservadora, como o de Frobes - que data de 1917 a 1920 - (consultei a tradução espanhola de 1950) e o de G. Dwelshauvers, 1929 (1930 pp. 43-54). Estes, no entanto, e outros de que são exemplos, defendem a introspecção como método psicológico válido — o que não significa necessariamente que o apresentem como o método da psicologia.

Durante o século XX a questão seria reaberta, mesmo dentro dos limites da psicologia acadêmica — não apenas por intermédio de autores, como R. S. Woodworth (1968), cuja "psicologia 
dinâmica" exprimia uma tendência funcionalista, quanto de behavioristas libertos da ortodoxia de Watson, à maneira de Tolman (1951). E, em data bem recente, por David Bakan (1973) em seu brilhante estudo sobre a "reconstrução da investigação psicológica"..

Mas esta é uma outra face do problema, que será retomada e debatida em momento oportuno.

\section{CAPÍTULO ॥}

\section{O legado da psiquiatria tradicional}

Em 1927 Morton Prince fundou em Harvard uma "Clínica Psicológica”, com a explícita intenção de promover a realização de estudos conjuntos de psicologia clínica e de psicologia acadêmica (cf. Boring, 1957, p. 701). Não que a psicologia clínica tivesse se iniciado com Morton Prince. Na realidade, formalmente existia pelo menos desde 1896, quando Lightmer Witmer, após dirigir nos dois anos anteriores um seminário sobre problemas do comportamento infantil, organizou uma "clínica psicológica" na Universidade da Pensilvânia (cf. Misiak e Sexton, 1968, pp. 194-223).

A referência a Morton Prince justifica-se pela preocupação central que externava. Pois os psicólogos acadêmicos, responsáveis pela construção dos sistemas psicológicos teóricos, mantiveram claro distanciamento da psicologia clínica — e esta em sua maior parte ignorou a psicologia sistemática, como se fossem campos científicos alheios um ao outro. Salvo no que se prende a Psicanálise - que, aliás, só incidentalmente abordou a temática geral da psicologia.

Tanto que o exame do conteúdo de obras "clássicas", referentes à história da psicologia, tais como as de Brett (1963), Boring (1957), Murphy (1960), Heidbreder (1933) e Flugel (1953), comprova que quase nada contêm sobre a psicológica clínica. É certo, todos eles citam Freud, Charcot, Jung, Boring e Flugel (ou pelo menos um dos dois) mencionam terapeutas egressos do mesmerismo e da hipnologia (Elliotson, Braid, Esdaile), psicanalistas das primeiras décadas (Ferenczi, Adler), psicopatologistas de vários quadrantes, desde Pinel e Esquirol e Janet e Ribot, chegam mesmo a Morton Prince, passando por Kraepelin, Liébault, Kretschmer. Abordam tópicos intitulados "medicina e psicologia freudianas" (Brett), "Pinei a Charcot" (Murphy) e assuntos afins. Mas, a psicologia clínica, como tal, não aparece em nenhum momento nas obras de Brett, e Heidbreder e Murphy, recebendo tratamento tangencial em Boring (1957, pp. 701 e 730-731) e em G. Flugel (1953, pp. 283 e 344).

De outro lado, poucos entre os clínicos citados ocuparam-se da psicologia. As exceções, rigorosamente falando, reduzem-se a Ribot - que imprimiu uma direção psicopatológica à psicologia francesa de seu tempo (cf. M. Reuchlin, 1963, pp. 60-63) e talvez Janet.

Os demais usam com freqüência o vocabulário psicológico corrente emprestando-lhe sentidos que poderiam ser qualificados, pelo menos, como heterodoxos.

Contudo, há todo um importante legado da psiquiatria tradicional à psicologia, parcial e tardiamente absorvido, e em grande parte à espera ainda hoje de uma adequada atenção por 
parte da psicologia convencional. Um resumo desta história, até o advento da psicanálise, ajudará a equacionar o problema central aqui estudado.

\section{Desmistificação e re-mistificação das doenças Mentais}

Desde logo, somente a partir do século XVI, com J. Weyer, é que médicos concentraram seus interesses sobre a psicopatologia. Até então não se conhece uma psiquiatria distinta do restante da medicina. Dentro da medicina é que se encontra a primeira tentativa formal de se desmistificar as doenças mentais: coube a Hipócrates fazê-lo.

\section{De Hipócrates aos Consoladores}

Para Hipócrates (460-377 a. C.) estavam equivocados tanto os que supunham serem as doenças mentais divinas ou sagradas, quanto os que as tomavam como purgação imposta pelos deuses em vista de ofensas sofridas: "têm causas naturais, como as demais doenças". Hipócrates tentou a sedutora hipótese (cf. Singer, 1934, pp. 26-28) de encontrar uma relação harmônica entre os "quatro humores", os "quatro órgãos secretores" e os "quatro elementos básicos".

* A designação de cada um desses conjuntos por letras não consta em hipòcrates, nem, tampouco, o esquema acima. Pareceume útil assim dispor para tornar mais facilmente sumarizada a apresentação de seu pensamento.
Humores

$\begin{array}{ll}\text { A } & \text { sangue } \\ \text { B } & \text { bilis negra } \\ \text { C } & \text { bilis amarela } \\ \text { D } & \text { fleuma }\end{array}$

Órgãos secretores

fígado

baço vesícula biliar pulmões
Elementos básicos:

fogo

terra

ar

água.

Suas combinações, pensava hipócrates $\left({ }^{*}\right)$, teriam consequências importantes:
Combinação A-C
calor
Combinação D-B
frio
Combinação A-B
sequidão
Combinação D-C
umidade

Prossegue Hipócrates, como os compêndios geralmente repetem relacionando os "quatro humores" aos "quatro tipos de temperamentos":

$\begin{array}{ll}\text { Humores } & \text { Temperamentos } \\ \text { sangue } & \text { sanguíneo } \\ \text { bilis negra } & \text { melancólico } \\ \text { bilis amarela } & \text { colérico } \\ \text { fleuma } & \text { fleumático }\end{array}$


No seu entender, a saúde seria a conseqüência de uma equilibrada combinação entre humores. De seu desequilíbrio resultando as doenças, como temperamentos, classificadas em quadro grupos: sanguienas, melancólicas, coléricas e fleumáticas.

Com Hipócrates, e medicina de Cós manteve-se em nível bem superior à de Cnido. Esta, baseada em observações empíricas que justificam seu anterior prestígio, chegou a importantes resultados para a prática médica, tanto no que se refere ao exame do paciente, quanto a indicações terapêuticas. Mas, seria preciso acrescentar à observação um comportamento reflexivo - o que se alcançou graças à tendência racional de Hipócrates — para elaborar não apenas um corpo de recomendações práticas para os médicos, mas uma construção científica.

Hipócrates refere-se à histeria (1955, p. 39, Seção V, aforismo 35), atribuindo-lhe, inclusive, um conteúdo sexual. Contudo, como se pensava então e Galeno (131-200) reforçaria, supunha-se ser a histeria uma doença exclusivamente feminina, relacionada com o funcionamento do útero: falava-se em "inanição", "inflamação" ou "deslocamento" uterino. Serapião de Alexandria, adversário do racionalismo hipocrático, defendia ser a histeria causada pela irregularidade da menstruação. Galeno sustentava ainda que a histeria poderia ser provocada pela ausência prolongada de relações sexuais — note-se bem: a ênfase incidia sobre a sexualidade, não, sobre o erotismo (cf. I. Veith, 1973, p. 50).

A prática da medicina, ao longo do tempo de influência galênica, caracterizou-se pela aplicação de banhos, massagens, dietas, choques de enguias elétricas e utilização auxiliar da música. Mas, Galeno era de opinião (cf. Groote, 1967, p. 19) que muitas doenças graves poderiam ser curadas unicamente por meio de um "choque moral". Opinião compartilhada pelo "Galeno persa", Rhazes (Al-Razi) :865-925), que pôs em prática o parecer de Galeno (cf. Lian, 1945, p. 80; Alexander e Selesnick, 1966, pp. 98-99): Rhazes aplicou um "método de sua invenção" - o qual denominou psychoterapeusis - no tratamento, dizia, de certas paralisias de origem reumática e de outras doenças sem uma explicação plausível. A psychoterapeusis poderia ser empregada no tratamento de pacientes do sexo masculino. Como se pode ver no Quadro 2, a história de Rhazes, como a de Gabriel Baktichou, raia ao pitoresco. O "método de sua invenção" suscita muitos questionamentos, o que não representa episódio isolado nesta história.

Entre os judeus, Maimônides (1135-1204), médico e filósofo, descreveu a "evolução da melancolia em mania" e reconheceu a necessidade de se tratar as "doenças da alma" de modo semelhante ao que se faz em relação às "doenças do corpo". Aliás, Epicuro (341-270 a. C.) emprestara à filosofia um caráter terapêutico: "assim como a medicina em nada beneficia se não liberta dos males do corpo, assim também com a filosofia, se não liberta das paixões da alma". "Ninguém proíbia o jovem de filosofar nem impeça o velho de fazê-lo; pois ninguém nunca é imaturo ou maduro demais para conquistar a saúde da alma" (Carta a Meneceu). Cícero (106-43 a. C.) e Boécio (séculos V—VI) fizeram importantes reflexões sobre o papel curativo dos "consoladores". 
Quadro 2

Notícias sobre Gabriel Baktichou e Rhazes

. Gabriel Baktichou "teve a glória de curar no fim do século VIII a concubina do califa Al-Rashid", a qual tinha sido vitimada de uma estranha paralisia.

Reunindo os membros da corte "à sombra fresca do palácio", fez entrar o doente e, em presença de todos, fez menção de levantar afoitamente a sua saia. Assustada e movida pelo pudor que dera origem à paralisia, a favorita baixou os braços até então inertes" e ficou curada.

Com tal sucesso, o "douto médico foi coberto de dracmas e admitido entre os íntimos da corte".

Conta-se que até os quarenta anos, Abu Bakr Muhamad Ibn Zakaryia al-Razi (Rhazes) dedicara-se à lira e, eventualmente, à filosofia. Só a partir daquela idade teria se interessado pela ciência e pela prática da medicina. E, como viveu longa vida, fez-se reputado clínico, alquimista e físico: "o mais ilustre e original dos médicos do século IX".

Também se conta que em se encontrando em Bukhara, foi convidado a tratar de um califa acometido de insidiosa artrite.

Prossegue a crônica, uma vez realizado o exame de praxe, admitiu Rhazes sua intervenção, mediante a satisfação de algumas condições: em primeiro lugar, atender o cliente em local a ser determinado pelo facultativo e na ausência de qualquer pessoa; em segundo lugar, ter a sua disposição dois cavalos ajaezados.

E por tal lhe ter sido concedido, mandou transportar o enfermo até umas termas situadas fora da cidade (segundo alguns situadas no próprio palácio), onde o submeteu de início a um banho quente. Eis senão que à saida de seus escravos e se encontrando sozinho com o paciente, surpreendeu-o Rhazes, ameaçando-o de morte com uma faca. Diante de semelhante estímulo o paralítico senhor levantou-se e correu... Enquanto isso, Rhazes e seu criado esperaram por suas notícias: rápidos, acorreram aos cavalos, que para outro fim não tinham sido exigidos.

Como Ihe recomendava a prudência, a narrativa indica ter decidido Rhazes se esconder por certo tempo. Em seguida, devolveu os cavalos acompanhando uma carta, dirigida ao poderoso califa. Na dita carta, o "mais original dos médicos do século IX" confessava ter posto em prática um método de sua invenção, denominado psychoterapeusis. "Recuperado e feliz", o príncipe ignorou a indignação e o medo sob cujo impacto reagira e ofereceu a Rhazes a recompensa de "preciosos presentes".

Fontes: M Ristich de Groote, La Folie à travers les siècles, Robert Lafont, Paris, 1967; F. Alexander e S. T. Selesnick, História da Psiquiatria, IBRASA, São Paulo, 1966; G Lian, A medicina árabe e sua influência na civilização européia, CUPULO, São Paulo, 1945; J. A. S. Pérez, La ciencia árabe en la edad média. Instituto de Estúdios Africanos, Madrid, 1954; R Arnaldez e L. Massignon, " A ciência Árabe”, em René Taton, História Geral das Ciências, Tomo I, 3 o volume, Difusão Européia do Livro, São Paulo, 1959. 
Um olhar retrospectivo sobre o período até o momento focalizado indica a existência de fatos importantes mas episódicos na história da medicina e da prática do que viria a ser no futuro a psiquiatria. Hipócrates, Galeno, Rhazes. Outros poderiam ser ainda citados, como Asclepíades (124-45? a. C) , um dos adversários do método hipocrático (cf. Horta Barbosa, 1963, p. 77), Celso (25 a. C. - 50 d. C), Sorano (93-139) e, sobretudo, Aretaeus (50-130). Aretaeus foi o primeiro a descrever a personalidade pré-psicótica e a notar a existência de "intervalos de lucidez entre os períodos maníaco e depressivo" (cf. Alexander e Selesnick, 1966, p. 74; Altschule, 1976, pp. 140-141) e 161-162).

\section{Obstáculos e Preconceitos}

Durante alguns séculos, o avanço dos estudos sobre as doenças mentais seria obstaculizado por preconceitos, em geral apontados, mas cuja interpretação psicológica está por ser feita. Vilanova (1240-1313) tentou desenvolver uma medicina de base hipocrática, associada à magia. Pelo mesmo tempo, Pedro Albano (1250-1316) ignorou o conteúdo espiritual do pensamento então dominante e procurou realizar observações sobre os doentes mentais. Mas, crenças amplamente divulgadas relacionavam o comportamento histérico ao de "feiticeiras", a um tempo "vítimas" e "agentes" do demônio. Este, afirmava-se, poderia assumir forma humana e seduzir os menos acautelados a um "pacto formal". Pacto que, por sua vez, poderia envolver um "comércio carnal" talvez sem remissão, apresentando-se o diabo como íncubo ou súcubo. Na realidade, o quadro patológico parecia estar presente tanto entre os perseguidos quanto entre muitos perseguidores: o que não justifica uma ingênua generalização, pois fatores econômicos e políticos tiveram um papel não raro mais relevante do que os verdadeiramente religiosos e/ou psicopatológicos porventura envolvidos em cada caso.

Dessa "loucura coletiva", escreve llza Veith (1973, p. 66), resultou um extraordinário documento: o Malleus Maleficarum ("Martelo das Feiticeiras"). Obra escrita por Johann Sprenger e Heinrich Kremer, dominicanos ambos experientes inquisidores, para tanto designados através de uma bula do Papa Inocêncio VIII, "Sumis desiderantes affectibus", de 9 de dezembro de 1484. É difícil comentar o conteúdo do Malles Maleficarum sem parecer exagerado. Era ele composto de três partes (conforme a tradução inglesa de Montague Summers, 1969), cujos principais tópicos ou idéias sintetizo em seguida.

Trata a primeira parte dos três componentes indispensáveis da feitiçaria: o demônio, uma feiticeira e a permissão de Deus todo-poderoso. Aqui os autores relatam a "enormidade do número de feiticeiras" e de seus "crimes", analisam a possibilidade de crianças serem geradas por meio de relações com íncubos e súcubos e questões correlatas.

A segunda incide, em particular sobre o modo de agir das bruxas, como manifestam o poder do demônio, emprestando ao homem a forma de bestas, como lhe infligem certas enfermidades, impedem a procriação e o privam de "seu órgão viril". Os autores indicam ainda a maneira pela qual a feitiçaria pode ser anulada e dissolvida e os métodos de cura dos que demonstrarem boa vontade: "os remédios prescritos pela Santa Igreja contra Súcubos e Íncubos", para reduzir os efeitos de sua ação, restabelecendo o "poder de geração", eliminando a forma de bestas que acaso tivesse a vítima assumido. . . 
- A terceira e última parte concerne aos procedimentos judiciais, quer nas cortes civis quer nas eclesiásticas, contra as feiticeiras e todos os demais heréticos. Descrevem, ao lado de outros assuntos, o método de iniciação do processo; o número, qualidade e condição das testemunhas; o desenrolar do processo; e, finalmente, o julgamento e os diversos modos de pronunciamento de uma sentença "justa e definitiva".

Quase sempre a referência aos obstáculos e preconceitos em relação às doenças mentais concernem ao quadro acima descrito. Mas, não é este o único. Nem, tampouco, foi a idade média o tempo único em os preconceitos medraram e se impuseram obstáculos ao equacionamento adequado deste problema.

Desde logo, nem todas as doenças foram "explicadas" através da ação do demônio. Como faz ver Michel Foucault (1974, pp. 37-38), a partir do século XIII a "loucura" é com freqüência encarada como um vício (ver Quadro 3).

É, pois, coerente, o pensamento expresso e a conduta objetivamente constatada pelos poderosos do tempo em face dos alienados ("têtes aliénés"). Tanto no episódio das naves dos loucos ("Stultifera Navis"), que se repetiu várias vezes no século XV e início do século XVI, quanto no "grande internamento" do século XVIII.

Por esse tempo era bastante generalizado entre os médicos incluir-se entre os fatores determinantes da histeria e, por extensão, das psicopatias em geral, a ociosidade, a alimentação inadequada e outras características das classes economicamente privilegiadas. Seus clientes

- e não apenas os histéricos - eram na maior parte das vezes "de boas famílias" e não lhes custaria muito o tratamento recomendado: banhos (para Boerhaave, mergulho em água gelada), equitação, viagens ao estrangeiro, sangrias, purgativos, fumigações uterinas, jogos de salão, como o xadrez.

Quadro 3

Hierarquia das virtudes e dos vicios

\begin{tabular}{|ll|}
\hline Virtudes & Vícios \\
- Fé & - Idolatria \\
- Esperança & - Desespero \\
- Caridade & - Avareza \\
- Castidade & - Luxúria \\
- Prudência & - Loucura \\
- Paciência & - Cólera \\
- Suavidade & - Dureza \\
- Concordia & - Discórdia \\
- Obediência & - Rebelião \\
- Perseverança & - Inconsistância \\
\hline
\end{tabular}


Mas, de maneira geral, escapou-lhes que não desprezível parte das "feiticeiras" condenadas à fogueira e que apresentavam sintomatologia semelhante à observada em suas clientes não gozavam das mesmas regalias. Além disso, no século XVIII, a situação sócio-econômica econômica antes de tudo - das faixas "inferiores" da população, egressas de um longo período de medo e de luta por causas não muito bem definidas, perdida inclusive a frágil segurança dos antigos núcleos feudais, não era francamente favorável à manutenção de modelos sadios de comportamento $(*)$. O afluxo de grandes massas de indivíduos desesperados para os centros mais abastados, como Paris, não apenas aumentava o grau de sua indigência como o de suas reações "anormais": físicas, morais e psíquicas (comportamentais). E, de certo, sua proximidade física da corte e do poder, tornando ainda mais patente a distância social e econômica entre as classes, gerava um mal estar entre os privilegiados e constituía um perigo potencial para a manutenção daquele estado de coisas.

Nem todos os "loucos" davam oportunidade à condenação. Havia os epilépticos - e os falsos epilépticos - , numa vã tentativa de alcançarem um tratamento mais humano (não se dizia que os doentes mentais tinham resistência animal, podiam suportar as mais duras intempéries? ). Urgia um amplo programa de "saneamento".

Mas, tomando Paris como exemplo (Foucault, 1974; M. Ristich de Groote, 1967, pp. 121-182), se a "grande aventura do internamento na idade clássica" teve um objetivo de saneamento, tal saneamento consistiu sobretudo em repressão. Os possíveis questionadores e incômodos indicadores de um contraste tanto mais chocante quanto o natural cada vez mais se impunha ao sobrenatural, eram internados quase sem resistência e a um custo irrisório, em comparação com o alcance da empresa.

Desde o início do século XVII registrara-se caridoso - mas socialmente ineficaz — movimento em favor dos doentes e necessitados: camponeses, forçados das galés, crianças abandonadas. São Vicente de Paulo (1581-1660) foi a figura reconhecidamente de principal relevo nesse movimento. Aliás, São Vicente pretendia acolher os que espontaneamente o desejassem. Mas, a providência oficial foi impor o internamento, por bem ou por mal, criando-se uma milícia especialmente para esse fim. "Compelle intrare" — lembra (Foucault em sua dramática Histoire de la folie (1974), p. 54). Assim, o Hospital Geral, criado por Luís XIV em 1656, deveria acolher mendicantes, prostitutas, jovens que tivessem desobedecido à autoridade paterna, pessoas que tivessem de alguma maneira comprometido a honra da família, desrespeitado a religião ou o poder real... e doentes mentais. Estes eram designados como insanos, alienados, fracos, fracos de espírito, dementes e, conforme certas características de suas condutas, violentos ou furiosos.

Vários autores abordam os fatos aqui referidos. Contudo, a análise de Foucault (1974) contém algumas pistas interpretativas que me parecem de forte interesse, as quais aqui reúno, chamando a atenção para os aspectos que me parecem focais. Em primeiro lugar, lembro que os hospitais gerais criados na França, Inglaterra, Holanda, Alemanha, Itália e Espanha eram entidades administrativas direta ou indiretamente controladas pelo Estado, dirigidas por leigos - e não casas de saúde - , social e econômica entre as classes, gerava um mal estar entre os privilegiados e constituía um perigo potencial para a manutenção daquele estado de coisas.

Nem todos os "loucos" davam oportunidade à condenação. Havia os epilépticos — e os falsos epilépticos -, numa vã tentativa de alcançarem um tratamento mais humano (não se dizia que 
os doentes mentais tinham resistência animal, podiam suportar as mais duras intempéries? ). Urgia um amplo programa de "saneamento".

Mas, tomando Paris como exemplo (Foucault, 1974; M. Ristich de Groote, 1967, pp. 121-182), se a "grande aventura do internamento na idade clássica" teve um objetivo de saneamento, tal saneamento consistiu sobretudo em repressão. Os possíveis questionadores e incômodos indicadores de um contraste tanto mais chocante quanto o natural cada vez mais se impunha ao sobrenatural, eram internados quase sem resistência e a um custo irrisório, em comparação com o alcance da empresa.

Desde o início do século XVII registrara-se caridoso - mas socialmente ineficaz — movimento em favor dos doentes e necessitados: camponeses, forçados das galés, crianças abandonadas. São Vicente de Paulo (1581-1660) foi a figura reconhecidamente de principal relevo nesse movimento. Aliás, São Vicente pretendia acolher os que espontaneamente o desejassem. Mas, a providência oficial foi impor o internamento, por bem ou por mal, criando-se uma milícia especialmente para esse fim. "Compelle intrare" - lembra (Foucault em sua dramática Histoire de la folie (1974), p. 54). Assim, o Hospital Geral, criado por Luís XIV em 1656, deveria acolher mendicantes, prostitutas, jovens que tivessem desobedecido à autoridade paterna, pessoas que tivessem de alguma maneira comprometido a honra da família, desrespeitado a religião ou o poder real... e doentes mentais. Estes eram designados como insanos, alienados, fracos, fracos de espírito, dementes e, conforme certas características de suas condutas, violentos ou furiosos.

Vários autores abordam os fatos aqui referidos. Contudo, a análise de Foucault (1974) contém algumas pistas interpretativas que me parecem de forte interesse, as quais aqui reúno, chamando a atenção para os aspectos que me parecem focais. Em primeiro lugar, lembro que os hospitais gerais criados na França, Inglaterra, Holanda, Alemanha, Itália e Espanha eram entidades administrativas direta ou indiretamente controladas pelo Estado, dirigidas por leigos - e não casas de saúde - c cuja presença do médico em certos casos $\left(^{*}\right)$ não era sequer diária. Em segundo lugar, abrigavam, como referi logo acima, não apenas os alienados, como os demais "contraventoras" da ordem pública, religiosa ou social, "detidos por ordem de Sua Majestade". Um outro detalhe importante: inicialmente na Inglaterra, depois também na Franças e em outros países, foram criadas "workhouses" ou casas de correção, onde os internados se obrigavam a uma jornada diária de trabalho. Embora por caminhos tortos se reduzisse o erro - os caminhos não eram honestos; o possível acerto seria um subproduto acidental de uma ação que visava um lucro fácil, com investimento a baixo custo.

Finalmente, saliento ainda: forte preconceito cultural que faria da "loucura" uma reedição da "lepra", então erradicada da Europa, pelo menos na condição de problema social grave como fora alguns séculos antes, explicava a ojeriza, o medo, a vergonha que as doenças mentais, o doente mental despertava em seus familiares e em sua nação. O alienado era incômodo.

*Não disponho de informações seguras que me permitam dizer que tal se aplicava a todos casos. Eram incômodos o vagabundo, o perdulário, o filho ou filha que envergonhava a família, o desobediente, o contestador...O Estado não os punia, diz Foucault (1974, p. 65): tomava-os a seu cargo, assumia sua manutenção, apenas com o preço de sua liberdade individual, apenas defendendo a sociedade de seu convívio desagradável. 
Tudo funcionava a contento. Conforme ainda uma vez lembra Foucault, não era em prédios de antigos leprosários que alguns novos hospitais foram instalados? Tudo muito cômodo, tranquilizante de consciências e poderes e privilégios.

De qualquer sorte, mantinham-se os preconceitos, mantinhamse os obstáculos ao equacionamento adequado do problema. Era conveniente que fossem mantidos.

\section{Reação aos preconceitos}

Em todo caso, a partir do século XVI — dentro do quadro aqui em estudo — teve início ampla e cada vez mais contagiante reação aos preconceitos, que, até então se impunham inquestionáveis. Todavia, as pressões culturais e os valores do "zeitgeist" calavam ainda bem sensíveis para se supor uma mudança radical e imediata. Tanto mais no domínio das doenças mentais, que jamais se libertou de todo de um certo halo mágico e impenetrável.

A reação aos preconceitos, o questionamento da autoridade, da "psiquiatria" da Inquisição, veio não apenas de médicos. Veio também de educadores, como Juán Luís Vives (1992-1540), que chamou a atenção para o equívoco então dominante. Mas, o maior ruído, provocou-o Paracelso (1493-1541). Espalhafatoso em todos seus atos, assumiu o papel de contestador a um tempo da escolástica, de Galeno e de Avicena. Combateu a "caça às bruxas" e voltou, como Hipócrates, a atribuir causas naturais às "doenças que privam o homem da razão". Em estudo sobre a "dança-de-são-guido" (cf. Ilza Veith, 1973, pp. 110-111), apresentou concepções pessoais sobre a histeria: a "chorea lasciva", escreveu, "é uma simples opinião e idéia alimentada pela imaginação, afetando os que acreditam em tal coisa".

A reação aos preconceitos seria fortalecida pela contribuição de um homem prático, pouco instruído mas observador arguto, primeiro a tentar a aplicação do método experimental à medicina: Ambroise Paré (1510-1590). Sustentou Paré ser imaginária a coabitação com íncubos e súcubos. Mas, homem de seu tempo, ao tratar sobre as doenças mentais hesitava entre admitir fossem suas causas naturais ou sobrenaturais. Quanto à histeria, como os antigos, aceitava ser de origem uterina. No seu tratamento empregava curiosos aparelhos para fumigações do útero, além de recomendar às casadas procurarem com mais freqüência a "companhia de seus maridos" e às virgens, caminhadas a pé, dança e equitação.

Paré teve ainda a oportunidade de distinguir entre a incidência e características das doenças mentais nas populações urbanas e rurais: enquanto as mulheres habitando as cidades, no seu modo de ver apresentavam dificuldades de respirar, tristeza sem causa razoável, mania — sobremaneira quando são ociosas —, "vivem copiosamente de carnes" e deixam de ter relações sexuais e engravidar, "as jovens que vivem no campo não são afetadas por aquelas doenças, pois não passam seu tempo melancolicamente a sonhar, vivem frugal e rudemente e estão sempre ocupadas em algum trabalho". Estas são palavras e idéias do "célebre cirurgião Ambroise Paré", homem do século XVI, citadas por Ilza Veith em sua Histoire de I'Hystérie (1973, pp. 119 e ss.).

Um terceiro autor deve ser mencionado neste período: Hohann Weyer (seu nome aparece em diversas fontes com diferentes grafias). Weyer (1515-1588) foi o primeiro médico a 
concentrar seu interesse sobre a psicopatologia: por tal motivo, Gregory Zilboorg propôs que fosse considerado o fundador da psiquiatria moderna (cf. Alexander e Selesnick, 1966, p. 13; Veith, 1973, p. 113).

Relatam comentaristas da história da psiquiatria que Weyer documentou com a colaboração do exorcista Martin Antonio del Rio abusos na perseguição de indivíduos doentes, tendo, inclusive, registrado "verbalizações de pessoas emocionalmente perturbadas". Além disso Weyer desenvolveu minuciosa crítica do Malleus Maleficarum - crítica, dizia ele próprio, "teológica, legal, filosófica e médica". Entretanto, permaneceu muito envolvido pelas crenças dominantes na sua época, a ponto de admitir formalmente o que chamava estratagemas" de Satanás e de distinguir a existência de "verdadeiros mágicos", poderosos em face de seus conluios com o demônio - os quais deveriam ser castigados - e mulheres doentes, vítimas do "Grande Prestidigitador", as quais, por sofrerem de "feitiçaria passiva", deveriam ser tratadas em lugar de punidas.

Weyer escrevia em 1577. A feitiçaria voltaria a ser objeto de estudo de muitos outros especialistas. Em particular, deu ocasião a textos clássicos de Reginald Scot (1584), Thomas Willis (1680) e Esquirol (1838), incluídos na importante coletânea de Altschule (1976, pp. 201-206).

Fora do âmbito específico da psiquiatria, registram-se reações isoladas, expressivas como depoimentos, ineficientes como passos concretos para o estabelecimento de um novo clima: a "sinopse histórica das perseguições da bruxaria e da enfermidade mental", publicada em anexo ao ensaio sobre a "fabricação da loucura", de Thomas Szasz (1974) dá uma idéia do quadro que a obra, em seu conjunto, descreve.

A reação aos preconceitos, contudo, não se limitou a ser uma revisão da explicação demonológica da psicopatologia. Mais abrangente, alcançou a reforma dos "hospitais". A realidade era também aqui por demais gritante. Poucos anos após sua fundação, documenta Foucault (1974, p. 62) só o Hospital Geral de Paris abrigava cerca de 1\% de toda a população. E, bem se via, nem a caridade sincera, nem a ingênua coerção ditada pelo medo, nem a desonesta e astuta reclusão ajudaria a recuperação dos enfermos: dos enfermos e dos outros, ali confinados por decisão real, de Sua Majestade... Foi preciso que um crente em outros valores, Philippe Pinel (17451826), sob o calor da Revolução Francesa assumisse a afoita decisão de retirar simbolicamente as correntes que prendiam os "loucos" do Bicêtre (1793) e da Salpêtrière (1795), para uma nova atitude, uma nova mentalidade começar a se impor. Não, que a Revolução aceitasse de bom grado a pretensão de Pinel. Muito lhe custou convencer o novo poder, representado no caso por Georges Couthon: Couthon compunha um Robespierre e Saint-Just o triunvirato forte do Terror (como seus companheiros, foi guilhotinado em 1794). E quando afinal cedeu, cedeu sem pleno acordo e sob a condição de se responsabilizar Pinel por todas as possíveis conseqüências de seu ato, inclusive a de haver entre os "internados" eventuais adversários da Revolução. Dentro do contexto histórico, foi um ato de bravura e de fé. O diálogo então travado entre Pinel e Couthon vale a pena ser recordado. Reproduzo-o a seguir (Quadro 4). 
Quadro 4

Diálogo entre Philippe Pinel e Georges Couthon, 1793

Couthon: "Infeliz de ti, se nos enganares, e se entre os loucos, esconderes inimigos do povo". "Ah! Cidadão! Será que tu mesmo és louco, a ponto de quereres as cadeias desses animais?"

Pinel: "Cidadão, estou convencido de que esses alienados só são desse modo intratáveis porque são privados de ar e de liberdade".

Couthon: "Muito bem. Faze o que quiseres; mas tenho receio de que venhas a ser vítima de tua presunção!

Fonte: M. Ristich de Groote, La folie à travers les siêrcles. Robert La font, Paris, 1967.

Foi preciso que a reforma dos "hospitais" proporcionasse a caracterização dos "hospitais psiquiátricos" - fato isolado considerado por Alexander e Selesnick (1966, p. 159) como o mais importante na história do estudo e terapia dos psicóticos — para que a reação aos preconceitos apresentasse resultados mais concretos. Nesta história a Salpêtrière e o Bicêtre são exemplos obrigatórios.

A "presunção" de Pinel gerou frutos. O primeiro deles brotou logo em 1796: William Tuke (17321822), entusiasta de Pinel, fez tratar com "benevolência, conforto e simpatia" os pacientes do York-Retreat, que ele próprio fundara a teria continuidade através de seu filho Henry e, de modo particular, de seu neto Samuel Tuke. Os restantes viriam nascendo: em 1789 Chiarugi (1759_ 1820) reformaria a organização hospitalar de Florença; Pisani (1760 - 1837) faria o mesmo em 1824 em Palermo; Langermann (1768-1832), na Alemanha; Conolly (1794-1866) aboliria a camisa de força no asilo de Hanwell (Inglaterra)

— "no restraint" e "open door"', pregava ele.

\section{Para a construção da psiquiatria moderna}

A esta altura e nos limites da meta a que pretendo chegar com estas considerações, chamo a atenção do leitor para alguns detalhes do quadro. De certo, o clima na idade média favorecia a "fabricação da loucura", cujo processo e cujo produto Thomas Szasz analisa em obra contundente (1974) e de que o Malleus Maleficarum dá o mais eloquente testemunho. Clima que seria reforçado pelo ambiente dos "hospitais gerais" e pelos fatores culturais subjacentes à idéia de sua criação. A reação aos preconceitos dar-se-ia nas duas frentes.

Todavia, nos dois casos essa reação teria um progresso bastante irregular, defendendo não raro "hipóteses" tão ingênuas quanto as refutadas. De um lado, os principais advogados dos enfermos em face da Inquisição chamavam-se Paracelso, Ambroise Paré e Johann Weyer quero dizer: não oscilavam todos eles entre certas evidências que constatavam e as crenças fantásticas que ingenuamente assimilavam? Ora, o mesmo Weyer que discutia cada artigo 
do Malleus Maleficarum, admitia a existência de nada menos do que 7.450 .926 perigosos demônios, divididos em 1.111 legiões e submetidos a 72 príncipes: Lúcifer, Belzebu, Satan e Asmodeu seriam as vedetes desse "inferno superpovoado" (cf. M. R. de Groote, 1967, p. 66), pondo em constante risco a saúde mental das pessoas. De outro lado, o progresso científico era também discutível. Pinel, ele próprio defendia como um "dogma médico" que os psicóticos teriam resistência animal e poderiam sofrer a ação de intempéries, como o frio mais rigoroso e prolongado, sem qualquer dano (cf. Foucault, 1974, p. 93).

Portanto, a construção da psiquiatria moderna teve por bases iniciais alicerces não muito estáveis. Tampouco seriam mais seguras as informações de que se nutriria, ao tentar um apoio na ciência. Sobretudo quando este apoio foi procurado em um conjunto de hipóteses que poderiam ser chamadas paracientíficas.

\section{As Hipóteses Paracientíficas}

Três problemas, por vezes parecendo paralelos, por vezes apresentando interseções com a temática aqui tratada, foram objeto de inquietantes e "paracientíficas" pesquisas: a aventura do vitalismo, o magnetismo animal e a frenologia.

\section{A aventura do vitalismo}

O século XVII foi o centro no tempo dessa história. Mas o vitalismo como problema prosseguiu sendo tema de investigação de filósofos e, se assim posso me expressar, biofilósofos, até o século XIX. De modo que, junto aos novos achados da ciência coexistiram suposições que, se comprovadas, teriam possivelmente alterado de maneira significativa a direção da ciência contemporânea e explodiram nas formas dos arqueus, da iatroquímica, do mediador plástico, do flogístico.

Há uma forte tendência para o estabelecimento de uma quimiatria médica. Paracelso volta à cena. Para ele todos os fenômenos vitais, normais ou patológicos — inclusive os psicopatológicos — teriam uma explicação química. De acordo com Paracelso (cf. Daumas, 1957, pp. 847 e ss.), a matéria compreenderia cinco princípios reunidos em duas categorias, conforme o esquema contido no Quadro 5.

\section{Quadro 5}

Categorias e princípios da matéria

\begin{tabular}{|ll|}
\hline Categorias & Princípios \\
- Princípios próximos & - Volátil (mercúrio) \\
& - Combustível (enxofre) \\
& - De resistência ao fogo (sal) \\
- Produtos extremos da & - Líquido destilável (fleuma) \\
destilação & $\begin{array}{l}\text { - Resíduo não destilável } \\
\text { (esqueleto: "tête morte") }\end{array}$ \\
\hline
\end{tabular}

Fonte: M. Daumas. Histoire de la science. Gallimard, Paris. 1957. 
* Harvey

(1578-1657) em memorável obra intitulada Exercitatio Anatomica de Motu Cordis et Sanguinis in Animalibus, publicada pela primeira vez em 1628, sustentara contra Galeno, não serem espíritos mas sangue, o que corria nas artérias (1955, p. 269).
J. B. Van Helmont (1577 - 1644) - que se considerava discípulo de Paracelso - desenvolveu um pensamento na mesma linha, apoiado em uma terminologia de simbolismo duvidoso, em parte originada do próprio Paracelso. Às raízes dos antigos, Van Helmont contrapôs a noção de "alcaest", substância agente e dissolvente de todas as coisas. Os fenômenos vitais seriam comandados pelos "arqueus". Estes são descritos de maneira cabalística e dispostos de acordo com uma hierarquia, atribuindo-se ao "arqueu supremo" o poder generativo. Aos "arqueus" subordinam-se os "blas", cabendo ao "blas humanum" presidir todas as funções corporais "especificamente humanas" e aos demais, as restantes "funções fisiológicas". A vida resultaria, assim, de um conjunto de ferramentas, fusões, sublimações, precipitações, destilações e reasções entre ácidos e álcalis. (Cf. Singer, 1934, p. 388; Horta Barbosa, 1963, p. 131).

Das idéias de Paracelso e Van Helmont originou-se a iatroquímica. No plano "teórico", a doutrina iatroquímica constituiu em reduzir - exatamente como tinham feito Paracelso e Van Helmont - os fenômenos vitais a combinações químicas. No domínio "aplicado", em explorar expedientes químicos no tratamento dos doentes, qualquer que fosse o gênero da enfermidade. Sylvius (1614-1672) (nome latino de François Le Boe, Leboe ou Dubois), principal animador dos iatroquímicos, contornou as noções de arqueus e blas, propondo o de fermentação. Em última análise, a iatroquímica representava a continuidade do sonho do superpoder da química, associada em suas origens alquimistas a esperanças mágicas e místicas, vagamente pretensas filosóficas. Finalistas e vitalistas, os iatroquímicos atribuíram aos processos vitais causas imprecisas, como "forças especiais", responsáveis pela "harmonia da vida".

A iatroquímica opuseram-se os iatromatemáticos, à frente Santório-Santório (1561-1636) e G. Alfonso Borelli (1608-1679), seu verdadeiro fundador, na opinião de L. Dulieu (1960, p. 196). A iatromatemática logo evoluiu para o que se chamou iatrofísica e a iatromecânica. De inspiração cartesiana, pelo menos em parte, pretenderam seus defensores ser o homem uma máquina, explicando-se a saúde ou as enfermidade de modo estritamente mecanicista: o funcionamento da matéria viva dependeria apenas da ação sobre ela exercida pela matéria não viva. O estudo do funcionamento do organismo e o tratamento das doenças em geral partiria de "dados objetivos": pesos e quantificações. A iatromecânica contou com expressivos componentes ou, pelo menos, simpatizantes, entre os quais Wílliam Harvey $\left({ }^{*}\right)$, G. Baglivi (1668-1706) e G. Cheyne (1671-1713).

A hipótese da existência de um agente químico universal encontrou em John Mayrow (1641_ 1769) um outro ardente partidário. Para ele esse agente - que denominou "espírito nitroaéreo" ("esprit nitroaérien") — seria a "parte ativa" do ar: noção vizinha à do oxigênio, como observa M. Caullery em seu estudo sobre "as grandes etapas da ciência biológica" (1957, pp. 879-882).

Da iatroquímica e da iatromecânica nasceriam dois "novos" sistemas médicos e duas hipóteses sobre a vida: o humorismo e o solidismo. O primeiro foi apresentado por Friedrich Boffmann (1660 - 1742) e propunha que o funcionamento do corpo seria semelhante ao de uma máquina hidráulica: tratava-se de uma volta à "teoria dos humores", de Hipócrates, com evidente associação à então jovem descoberta de Harvey. O segundo é atribuído a Hermann Boerhaave (1668- 1738). Boerhaave não pensava no corpo como sendo exclusivamente sólido, mas sim formado de sólidos "mergulhados em humores". 
Tais proposições não satisfaziam a todos. Seguindo uma outra linha de pensamento, buscando conciliar o dualismo com as novas colocações sugeridas pela química, Ralph Cudworth (16171688) defendeu a composição de três elementos na vida humana: o corpo, a alma e o mediador plástico (cf. Barbado, 1931, p. 49). A hipótese de Cudowrth, especulativa mas com pretensão científica, alcançou bastante repercussão, a ponto de P. Janet ter publicado em 1860 todo um ensaio a seu respeito.

Contra ela e contra a iatroquímica escreveu Ernest Stahl (1660 - 1734). Também Stahl se deixou seduzir pelo sonho da existência .de uma substância agente universal, que chamou de flogístico (ou flogisto). Embora tão equívoca quanto as propostas que combateu, suas idéias prevaleceram até que Lavoisier (1743-1794) demonstrasse sua inoperância. Em Theoria Medica Vera, obra publicada pela primeira vez em 1708, Stahl postulou uma explicação vitalista e ao mesmo tempo animista, ao defender ser a alma "princípio de vida" e "causa de todas as funções orgânicas": "arquiteta de seu próprio corpo".

Particularmente importante para o presente trabalho é notar suas idéias concernentes à patologia e à terapêutica. Distinguiu Stahl a "terapêutica natural" da "artificial" - a primeira sendo desenvolvida pela alma ("a alma é a médica natural de seu corpo") e a segunda, pelo médico (a medicina é uma "arte auxiliar e imitadora"da alma). Portal razão a iatroquímica é para ele inócua, inócua qualquer utilização da farmácia. (Cf. A. Lemoine, 1864; Nordenskiold, 1949; Daumas, 1960; Canguilhem, 1960).

O vitalismo, associado ou em oposição ao animismo, associado ou em oposição à quimiatria, teria uma longa e instável história, da qual Xavier Bichat (1771-1802) participa com um papel relevante. Em clássico ensaio denominado Pesquisas fisiológicas sobre a vida e sobre a morte, cujá primeira edição data de 1801 (consultei a de 1859), Bichat considera a vida, "modo geral de existência dos corpos vivos", como o "conjunto de funções que resistem à morte". Admite a realidade de duas vidas no homem, a animal e a orgânica, cujas diferenças gerais estão sintetizadas no Quadro 6. Bichat supunha que tudo o que se referisse ao "entendimento" pertenceria à vida animal, enquanto o que se relacionasse às paixões pertenceria à vida orgânica; entretanto, reconhece que as paixões modificam os atos da vida animal no que concerne às "forças vitais" (sensibilidade e contractibilidade) e aos tecidos (extensibilidade e contractibilidade). Bichat tece considerações sobre a origem e desenvolvimento da vida orgânica e animal, admitindo que esta sofreria a influência da educação e da sociedade.

Os equívocos do vitalismo não terminam aqui. Em todo caso, não se pode negar que o vitalismo representou episódicas mas importantes antecipações, apesar da redução quimiátrica ter caído em descrédito, de sua discutível significação como projeto científico.

\section{Do magnetismo à hipnose}

Os reducionismos mágicos são quase sempre atraentes. O alcaest. O flogisto. A iatroquímica. Os fluidos universais. Não é de se estranhar que a crença na alquimia, na transforrração dos metais, na pedra filosofal tenha se insinuado com tanta insistência como meios de redução da vida e do universo a um conjunto de noções simples e por sua vez irredutíveis, cujo conhecimento de certo modo daria a chave para o conhecimento de todas as coisas. 
Vinha de longe a idéia de se comparar a "atração" existente entre as pessoas à constatada entre o ferro e o imã. Aristóteles já dissera que o ferro se move para o ímã como o amante para a amada (cf. Wiener e Noland, 1971, p. 18). Em 1600 William Gilbert (1540-1603). enunciaria sua teoria do magnetismo: De Magnete. Gilbert pensava - e com ele concordaria Kepler (1571 - 1630) - que a gravitação seria um fenômeno magnético. Defendia o valor medicinal do ferro e o poder de animação do ímã, que "imita" e às vezes "supera" a alma do homem. Lembrava alguns filósofos, à maneira de Platão, que admitiam a existência de uma "alma do mundo" (cf. Gjlbert, 1955,pp. 20-21 e 104-105).

O sucesso de Gilbert na física, junto às insinuações relativas à alma e a sua semelhança com o poder de atração do ímã, presentes em De Magnete, reanimou a velha chama ainda viva mas já questionada por muitos: ainda aqui vem à cena o controvertido Paracelso, para quem o homem

Quadro 6

Diferenças gerais quanto à vida (Xavier Bichat, 1801)

\begin{tabular}{|c|c|c|}
\hline \multirow[b]{2}{*}{ em relação } & \multicolumn{2}{|c|}{ Diferenças gerais quanto à vida } \\
\hline & animal & e orgânica \\
\hline $\begin{array}{l}\text { 1/ às formas exteriores de } \\
\text { seus órgãos }\end{array}$ & simetria & . irregularidade \\
\hline $\begin{array}{l}\text { 2/ ao modo de ação dos } \\
\text { órgãos }\end{array}$ & . harmonia & . discordência \\
\hline 3/ à duração de suas ações & . intermitência & . continuidade \\
\hline 4/ ao hábito & $\begin{array}{l}\text { embota os sentimentos } \\
\text { e aperfeiçoa o juízo }\end{array}$ & $\begin{array}{l}\text { tem pouca influência mas } \\
\text { modifica alguns fenômenos }\end{array}$ \\
\hline 5/ à moral & $\begin{array}{l}\text {. envolve tudo o que é rela- } \\
\text { tivo ao "entendimento" }\end{array}$ & $\begin{array}{l}\text { envolve tudo o que é } \\
\text { relativo às paixões }\end{array}$ \\
\hline
\end{tabular}

Fonte: Xavier Bichat, Recherches physiologiques sur la vie et sur la mort. Charpentier, Paris, 1859.

teria "o poder de afetar objetos distantes", inclusive de "afetar seus semelhantes e curá-los". Entretanto, sobretudo entre os séculos XVII e XIX, passou pelo pensamento de William Maxwell (15811641) concernente ao "fluido universal", pelas curas de William Greatakes (1629-1683), para chegar ao magnetismo animal do mesmerismo. Sem julgar a honestidade pessoal de Franz Anton Mesmer (1736-1815), a leitura de suas Memórias e Aforismos sobre o Magnetismo Animal (consultei a edição de 1862) revela uma focalizaçlo de tal modo ingênua que justifica a suposição de deliberado charlatanismo, É, de fato, surpreendente que tenha contado com alguns médicos entre seus adeptos, ainda que a maioria de seus "clientes" compreendesse indivíduos ignorantes, crédulos ou histéricos. Como escrevem Chertok e Saussure (1973, p. 21), o que, aliás, agravava ainda mais a possível conseqüência social de sua ação, "inúmeros foram os que, uma vez magnetizados, consideraram-se, por seu turno, autorizados a magnetizar. $\mathrm{O}$ magnetismo tornou-se um jogo de salão". 
Ao corpo geral de sua "doutrina" Mesmer deu o nome de "magnetismo animal", por considerar que o "magnetismo metal" não seria indispensável, podendo o tratamento ser efetuado através apenas do magnetizador, tomado como "fonte de magnetismo". Tudo no universo está em contato, pensava ele, através do fluido universal, invisível e impalpável, no qual "todos os corpos estão mergulhados" (cf. Mesmer, 1862, pp. 40 e ss.; Veith, 1973, pp. 219-225).

No seu entender, a doença é o resultado do desequilíbrio do fluido universal em um dado sujeito, cuja cura requer ser colocado "em contato com a fonte desse fluido". A terapia de Mesmer se desenvolvia em um ambiente mágico e consistia em um ritual que em nada lembrava a prática médica então vigente. Embora atendesse a seus pacientes isoladamente, preferia fazêlo em grupos, pois assim, dizia, o poder do magnetismo seria consideravelmente aumentado. Na sala adrede preparada para cada sessão (termo empregado por Mesmer), deveria haver um recipiente ("bacquet") contendo água e limalha de ferro "magnetizada". Sua aparição era dramática e artificial, ao som de uma música suave. Obtinha o "rapport" (termo do próprio Mesmer, que o definia como "contato afetivo") tocando os presentes um a um. Recomendava tocar em primeiro lugar as vísceras, "para descobrir a causa da moléstia", com o polegar e o indicador ou com a palma das mãos ou ainda apoiando seus joelhos contra os joelhos dos pacientes. Entretanto, recorria por vezes a condutores estranhos (vidro, ferro, ouro, prata, aço...), os quais deveriam ter a forma de uma "varinha de 10 a 15 polegadas". Os pacientes entravam em "transe sonolento" — sono mesmérico —, ao fim do qual se sentiam muito bem. O marquês de Puységuir (1751—1825), um de seus seguidores mais entusiastas, sustentava que o "sono acordado" de sujeitos "mesmerizados" operava "verdadeiros milagres". Com o método acima descrito, pretendia Mesmer substituir o "diálogo verbal" pelo "diálogo somático".

A prática do mesmerismo suscitou, de início em Viena, posteriormente em Paris, muitas controvérsias. Tanto que o Rei Luís XVI designou em 1784 duas comissões (cf. Chertok e Saussure, 1973, pp. 22-26) encarregadas de omitirem pareceres sobre o valor científico do magnetismo animal. A primeira era formada por quatro professores da Faculdade de Medicina e cinco membros da Academia de Ciências, entre os quais Benjamin Franklin, o astrônomo Bailly, Lavoisier e Guillotin. A segunda, por cinco representantes da então Sociedade Real de Medicina, entre os quais, Jussieu. Cada uma elaborou um Relatório, publicados em separado mas coincidentes em suas conclusões: pela inexistência do fluido universal e a ineficácia do magnetismo animal — os "fenômenos magnéticos" resultam da imaginação. Do Relatório de Bailly: "a imaginação sem magnetismo produz convulsões...o magnetismo sem a imaginação não produz nada".

O magnetismo animal foi proibido na Universidade de Paris e os bens de Mesmer foram confiscados pelos jacobinos.

Mas o mesmerismo - termo proposto por Karl Wolfhart para substituir magnetismo animal - continuaria atuante. E até o século XIX receberia acréscimos e modificações resultantes de contribuições de magnetizadores diversos. Puységuir, já mencionado, ressaltou que o magnetismo seria beneficiado pela "vontade do paciente" em curar. Deleuze (1753 - 1835) se apercebeu do possível envolvimento afetivo entre o magnetizador e o magnetizado: relatou experiências pessoais, suas, a este respeito, mas confessou que ao cabo de alguns dias o sentimento deveria ser superado, devendo ser substituído, no caso do magnetizador, pelo "prazer de fazer o bem". Em Le Magnétiseur amoureux Charles de Villers (1775-1846) abre perspectivas para o relacionamento entre o magnetismo e a sugestão. Idéia que seria enfatizada pelo abade 
Faria (1755-1819), para quem nada decorreria do terapeuta, "tudo se passa no espírito do sujeito" (cf. Chertok e Saussure, 1973).

Paulatinamente, na medida em que se avançava no século XIX, o mesmerismo cedia lugar à hipnose - e aqui alguns entenderão que o qualificativo paracientífico não seria tão adequado. John Elliotson (1791 - 1868), médico inglês, praticou o mesmerismo sob forte pressão de seus colegas: interessava-se Elliotson sobretudo pelo "sono mesmérico". James Esdaile (1808-1859) - como outros, inclusive Broca, logo o fariam - aplicou o sono mesmérico como anestesia em intervenções cirúrgicas. Braid, médico escocês, admitiu a utilidade do "sono mesmérico" ou "nervoso", propondo substituir a terminologia em voga, desacreditada pela ciência, por um vocabulário novo. Falava Braid, em lugar de magnetismo animal ou magnetismo metal, de hipnologia. Hipnotismo. Ou braidismo, como sugeriu J. P. Philips em 1860.

As idéias do Braid encontrariam eco e continuidade nos trabalhos de Liébault (1823-1905) e Bernheim (1840-1919), na Clínica de Nancy, onde se enfatizava o poder da sugestão, e Charcot (1825-1893) e Pierre Janet (1859-1947), na Salpêtrière.

Não obstante seus desacertos, as idéias de Mesmer contribuiram de modo inequívoco para o fortalecimento da tendência psicodinâmica na medicina e na psicologia.

\section{A frenologia}

Um terceiro núcleo de interesses, dentro dos limites das "hipóteses paracientíficas" é centrado sobre o estabelecimento de relações de dependência entre os traços fisionômicos (fisiognomonia) ou a circunvoluções do cérebro (craniologia, frenologia), de um lado, e, de outro, a conduta moral e afetiva dos indivíduos. Lavater, Gall e Spurzheim foram os sistematizadores dessas explicações errôneas, mas em seu tempo, fascinantes.

Em 1775 (cf. Varet, 1956, T. II, p. 761) o pastor suíço Johann Kaspar Lavater (1741-1801) iniciava a publicação de uma confusa e mal realizada obra: sua edição original compunhase de 4 volumes. Consultei a segunda tradução francesa, L'Art de Connaítre les Hommes par la Physionomie, cuja publicação foi iniciada em 1820 e incluiu as nem sempre oportunas anotações dos editores, professores da Faculdade de Medicina de Paris. Essa edição perfez um total de 10 volumes: para a finalidade do presente estudo, limitei-me ao primeiro, que continha a parte geral.

Propunha Lavater o reconhecimento de uma nova "ciência" por ele criada, a fisiognomonia: "estudo do homem interior e moral, pela observação do homem exterior e físico" (cf. Ysabeau, s. d., p. 5). A fisiognomonia, dizia Lavater (1820, I, p. 223), "é a ciência que ensina a conhecer a relação do exterior com o interior, da superfície visível com o que ela envolve de invisível, da matéria animada e perceptível que lhe imprime o caráter de vida, do efeito manifestado com a força escondida que o produz".

Lavater pretendia que a pesquisa se efetuasse sobre todo o corpo, "em movimento" ou "em repouso", mas sua ênfase recaiu sobre a fisionomia: fronte, olhos, sobrancelhas, nariz, boca, dentes, queixo, bochechas, pescoço, cabelos. Sustentou ser possível através dessa análise identificar as características individuais, tanto intelectuais quanto morais e afetivas. As paixões que a fisionomia exprime podem ser convulsivas, pressivas ou expansivas. 
No estudo dos "sinais fisiognomônicos", indicadores dos diversos temperamentos, analisa a reação de quatro homens em face de um "estímulo": um quadro representando Napoleão à beira de um abismo na ilha de Santa Helena. Trata-se, por certo, de um estilo de exame surpreendentemente moderno. Além disso, ao lado de suas ingênuas divagações, Lavater revelou ser hábil observador de comportamentos humanos, chamando a atenção para as semelhanças e diferenças entre os indivíduos, em relação a grupos familiares, nacionais, de idade e sexo.

Lavater parece ter alcançado maior êxito em sua atividade "aplicada" do que em suas considerações "teóricas". De fato, sua obra foi recebida com muita reserva nos meios científicos; mas, como "prático", obteve notável prestígio, sendo procurado em Zurique, onde vivia, por clientes vindos de várias partes da Europa, alguns deles de projeção política ou intelectual, que se submetiam a exames e recebiam conselhos, sobretudo concernentes a "disposições morais".

Com Franz Joseph Gall (1758 - 1828), a fisiognomonia evoluiu para a organologia ou craniologia. Gall expôs seu pensamento em uma obra cujo título, pelo menos por curiosidade, vale a pena lembrar: Anatòmie et Physiologie du Système Nerveux et du Cerveau en particulier, avec des observations sur la possibilité de reconnaitre plusieurs dispositions intellectuelles et morales de l'homme et des animaux par la configuration de leurs têtes. Compunha-se de 4 volumes, os quais foram publicados entre 1810 e 1819.

Posteriormente, considerando o que ele próprio escrevia (1822, 19 V., p. ii), o êxito dessa "obra magnífica", "presente nas principais bibliotecas da Europa", levou-o a escrever um novo livro que fosse digno do tema, onde exporia de maneira pormenorizada sua "doutrina sobre as funções morais e as faculdades intelectuais do cérebro". Intitulou o novo trabalho: Sur les fonctions du cerveau et sur celles de chacunne de ses parties (6 volumes, 1822 a 1825).

Em geral, os críticos e historiadores reconhecem qualidades positivas em Gall como neuroanatomista, embora possivelmente não tanto quanto sua imodéstia o levava a crer. Antes o defensor de uma tese errada do que um charlatão (Taylor, 1965, p. 197), descobriu relações que suas pesquisas não autorizavam, enredando-se na teia que ele mesmo criara.

Gall pensava que Lavater estava equivocado quando relacionava aos traços fisionômicos as "faculdades intelectuais" e as "qualidades morais". A relação existente, afirmava, seria entre essas faculdades e qualidades e as circunvoluções do cérebro. Obviamente, seria impraticável sua observação. Dessa maneira, Gall imaginou que o estudo daquelas supostas relações deveria se realizar através do exame da conformação do crânio. Ao longo de sua obra, estudou com tamanha minúcia e segura crença, que é de se lastimar o esforço inútil que despendeu, tentando demonstrar o que considerava ser "Os quatro princípios fundamentais de toda a fisiologia do cérebro" (1822, p. vi; 1825, p. 499):

— "as disposições morais e intelectuais são inatas";

— "sua manifestação depende da organização";

— "o cérebro é exclusivamente o órgão da alma"

de "todas as tendências, sentimentos e faculdades";

—“o cérebro é composto de tantos órgãos particulares e independentes quantas são as forças fundamentais da alma". 
*Jorden, como nota Sylvie Dreyfus na tradução francesa da Histoire de I'Hystérie, de I. Veith (1973, p. 124), empregou o termo "mother" em lugar do corrente "matrix", para designar o útero, em relação à histeria.
A impressão que fica da leitura da obra de Gall confirma a opinião de Taylor, citada acima. Isto é, a de ter sido Gall um estudioso que seguiu uma falsa pista, que partiu de uma premissa falsa e chegou às quase inevitáveis conseqüências de seu erro inicial. O que não torna sua craniologia mais verdadeira do que a fisiognomonia de Lavater.

O termo frenologia, quase sempre indicativo da hipótese de Gall, é, na verdade, atribuído a Spurzheim (1776 - 1832), entusiasta de suas idéias e, durante algum tempo, seu colaborador — tendo até mesmo participado da redação de parte de suas obras. Spurzheim, no entanto, estava mais preocupado com a divulgação da frenologia do que com sua fundamentação científica (cf. Boring, 1957, p. 53).

Vitalismo, magnetismo, frenologia — fantasias ingênuas ou intuições profundas e mal conduzidas? As duas coisas, talvez. Talvez. Não é sem razão que Wolman (1970, p. 651) escreve ser a história da ciência uma história de erros. Pois, prossegue, a constatação do erro e as descobertas de confusões têm sido tão frutíferos quanto as hipóteses e descobrimentos positivos. Em todo caso, apesar do malogro de suas propostas, do halo de misticismo e fantasia que envolve seus enunciados, há neles um saldo de intuições profundas, de intuições brilhantes, embora não necessariamente verdadeiras. Lembro, por exemplo, certas colocações de Stahl sobre o poder curativo da alma e a inutilidade da farmácia. O sentido de catarse da "cura magnética" (cf. Chertok e Saussure, 1973, p. 53). O "teste" de Lavater, utilizando um estímulo objetivo capaz de suscitar reações subjetivas e pessoais. A vaga mas inevitável tendência personalista da frenologia

\section{Contribuições empíricas}

No entanto, ao lado dessas hipóteses paracientíficas, desenvolveu-se a partir do século XVII uma preocupação empírica que informaria em grande parte a psiquiatria e a psicologia clínica contemporâneas. Não, que se tratasse de uma colocação completamente nova. Hipócrates já o tentara. E muito do que foi dito aqui até o momento fundamentouse no empírico. Mas, agora, essa preocupação vai ser uma constante.

O método, não há dúvida, é cientificamente frágil: observações médicas. Nem controle. Nem medida. Nem quantificação. Entretanto, um mérito não se lhe pode negar, valioso do ponto de vista histórico. Ao contrário de se buscar a explicação apenas em um posicionamento racional, procura-se antes de tudo descrever — ou classificar — o que se vê. Como se vê. E se explicar, partindo-se do que se vê, embora essa explicação seja ainda muitas vezes ingênua.

\section{Séculos XVII e XVIII}

Pois o caminho é árduo e a renúncia aos preconceitos estabelecidos é sempre uma experiência difícil. As descobertas nem sempre são bem nítidas no início. Edward Jorden (1578-1632), por exemplo, parece ter inferido de suas observações o fenômeno da conversão. Jorden, no entanto, no seu Breve discurso sobre uma doença chamada "sufocação da mãe" $\left({ }^{*}\right)$, publicado em 1601, propôs a ingênua explicação de que "emanações" ou "vapores", partindo do útero, contaminariam outros órgãos. Embora a idéia de emanações ou vapores não fosse de todo desconhecida dos antigos, fez-se muito divulgada na Inglaterra dos séculos XVII e XVIII. Joseph Raulin (1708-1784) escreveria todo um Tratado das afecções vaporosas, as quais supunha 
contagiosas opinião, de resto, partilhada com G. Baglivi e Robert Whytt (1714-1766). Pierre Pomme, autor de estranhas observações (cf. Foucault, 1977, p. vii), escreveu um outro Tratado sobre o mesmo assunto, alcançando rapidamente várias edições. Cheyne (1671-1713) incluiria em seu estudo sobre a "doença inglesa" os "vapores", ao lado de outros tipos de "doenças noervosas", como a melancolia, a fraqueza de espírito, "destemperos hipocondríacos e histéricos".

Por sua vez, a idéia de conversão seria retomada de modo mais explícito por Thomans Sydenham (1624-1689), para quem os sintomas histéricos poderiam simular "quase todas as formas de doenças orgânicas" (cf. Alexander e Selesnick, 1966, p. 139). G. Baglivi admitia igualmente que as, "paixões do espírito" podem causar perturbações morais ou mesmo físicas.

Mas, a primeira conseqüência concreta deste modo empírico de encarar o comportamento dos pacientes a reformulação da crença em torno da suposta natureza uterina da histeria. Charles Le Pois (1563- 1633), em suas Observações Médicas, publicadas em 1618, negou que a histeria seja exclusivamente feminina e que resultasse da ausência prolongada de relações sexuais, como ensinara Galeno. E citava casos que acompanhara, de homens portadores de sintomas histéricos e de mulheres histéricas, "mesmo nos braços de seus maridos" (cf. Levy, 1914, pp. 103 e ss.). Nem mesmo Rhazes, aplicando com êxito sua psychoterapeusis, a um sultão, abordara o problema de modo tão direto. Entretanto, se logo outros autores, como Sydenham e Thomas Willis (1622-1675) confirmariam as observações de Le Pois, outros, entre os quais Robert Burton (1577-1640) continuavam a falar da histeria como sendo a "melancolia das virgens, religiosas e viúvas". Burton escrevia em 1621. Seu livro, intitulado Anatomia da Melancolia, é uma obra de leigo (consultei a edição de 1867), dramático e irônico depoimento sobre sua experiência pessoal de doente em face da sociedade de seu tempo. Nas palavras de W. R. Müeller (1952), é bem uma "anatomia da Inglaterra" o que realiza, não apenas uma anatomia da melancolia em si, mas da melancolia inglesa, de suas relações com a política e a religião na Inglaterra do século XVII .

Uma segunda conseqüência da observação empírica dos séculos XVII e XVIII incidiu sobre a compreensão de fatores sociais e culturais nos processos de agravamento e cura das doenças mentais. Ainda no século XVI, Ambroise Paré havia pensado ser a histeria uma doença urbana. Agora, quando vários seguiam uma corrente que se poderia dizer cerebralista (Le Pois, Th. Willis) ou propunham relações hipotéticas entre as cardiopatias e as "doenças nervosas" (Harvey), fortalecia-se a suposição de que certas doenças teriam origem em condições psicossociais (ou se agravariam em face desses condicionamentos) e seu tratamento deveria envolver os familiares do paciente, como recomendava Jorden. Cheyne, estudando a melancolia como modalidade da "doença inglesa" (desconhecida de "nossos ancestrais") imputava-a à "vida sedentária e das classes privilegiadas" e às condições características dos centros urbanos. Cheyne, como Robert Burton, fazia observações sobre seu próprio comportamento, pois se declarava ele mesmo enfermo. 


\section{Séculos XVIII a XIX}

No decorrer do século XVIII e por todo o século XIX, convivendo com as hipóteses paracientíficas ou as ignorando, registra-se uma verdadeira explosão de autores e de ensaios abordando a psicopatologia. São estudos em sua maioria de natureza empírica, como vinha acontecendo nos últimos cem anos, dando lugar a construções teóricas ou descritivas das doenças mentais. Embora por vezes reflitissem provável influência filosófica e psicológica — sobretudo no concrenente à investigação do comportamento emocional —, não há vinculação estreita entre os autores interessados na psicopatologia e os psicólogos.

Mas, se foi notável o acúmulo de observações empíricas e descrições baseadas em observações empíricas, sua validade continua discutível, pois, como no século XVII , caraciam de qualquer controle ou organização técnica das informações disponíveis, apresentando falhas não apenas metodológicas, por vezes também lógicas.

Desde logo, foi acentuada a motivação classificadora. Como vários analistas do tema advertem, parece responder ao que Lineu e outros vinham de ensaiar nas ciências naturais. A título de uma melhor compreensão desta história, elaborei esquemas relativos às classificações apresentadas por Sauvages (1706-1767), William Cullen (1712-1790) e Pinei, as quais compreendem respectivamente os Quadro 7, 8 e 9.

Cullen, primeiro a empregar o termo neurose (cf. Alexamder e Selesnick, 1966, p. 157; Veith, 1973, pp. 170; Pélicier, 1973, p. 70), classificava as doenças em quatro grandes grupos:
a) Febres;
b) Catexias;
c) Perturbações localizadas;
d) Perturbações não localizadas (neuroses).

Pinel, por seu turno, reuniu as enfermidades então conhecidas em cinco classes, as quais abrangiam ordens, subordens e gêneros. As classes propostas por Pinel são as seguintes:
a) Febres;
b) Inflamações;
c) Hemorragias;
d) Neuroses;
e) Lesões orgânicas. 


\section{Quadro 7}

François Boissier Sauvages: Classificação das doenças mentais (1763)

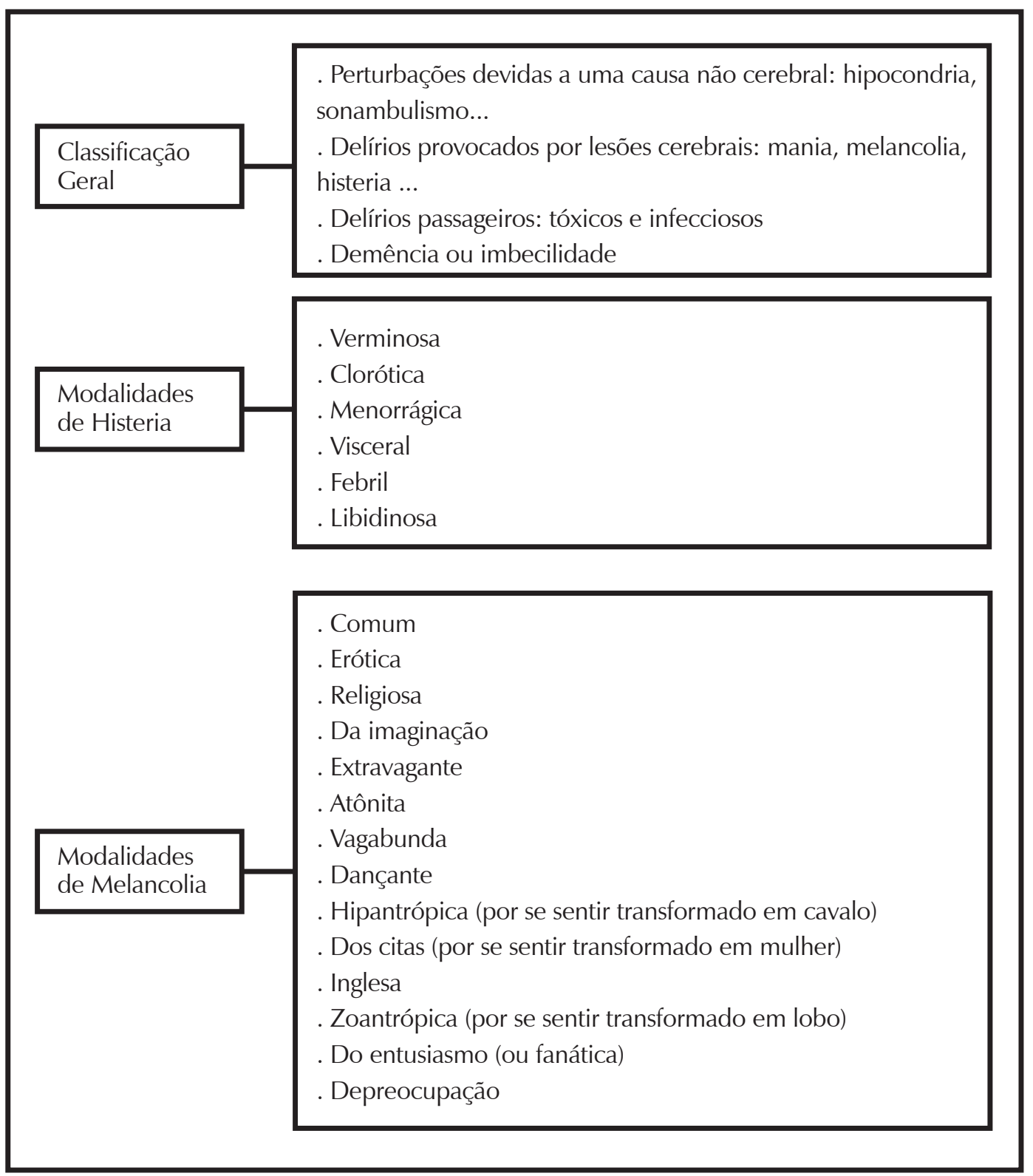

Fontes: I. Veith, Histoire de I'Hystérie, Seghers, Paris, 1973; Y Pélicier, História da Psiquiatria, Publicações Europa-América, Lisboa 1973; M. D. Altschule, The Development of Traditional Psychotology - a Sourcebook, Halsted Press, Hemisfere Publishing Corporation Washington, 1976. 
Quadro 8

William Cullen: Classificação das Perturbações não Localizadas (Neuroses) (1971)

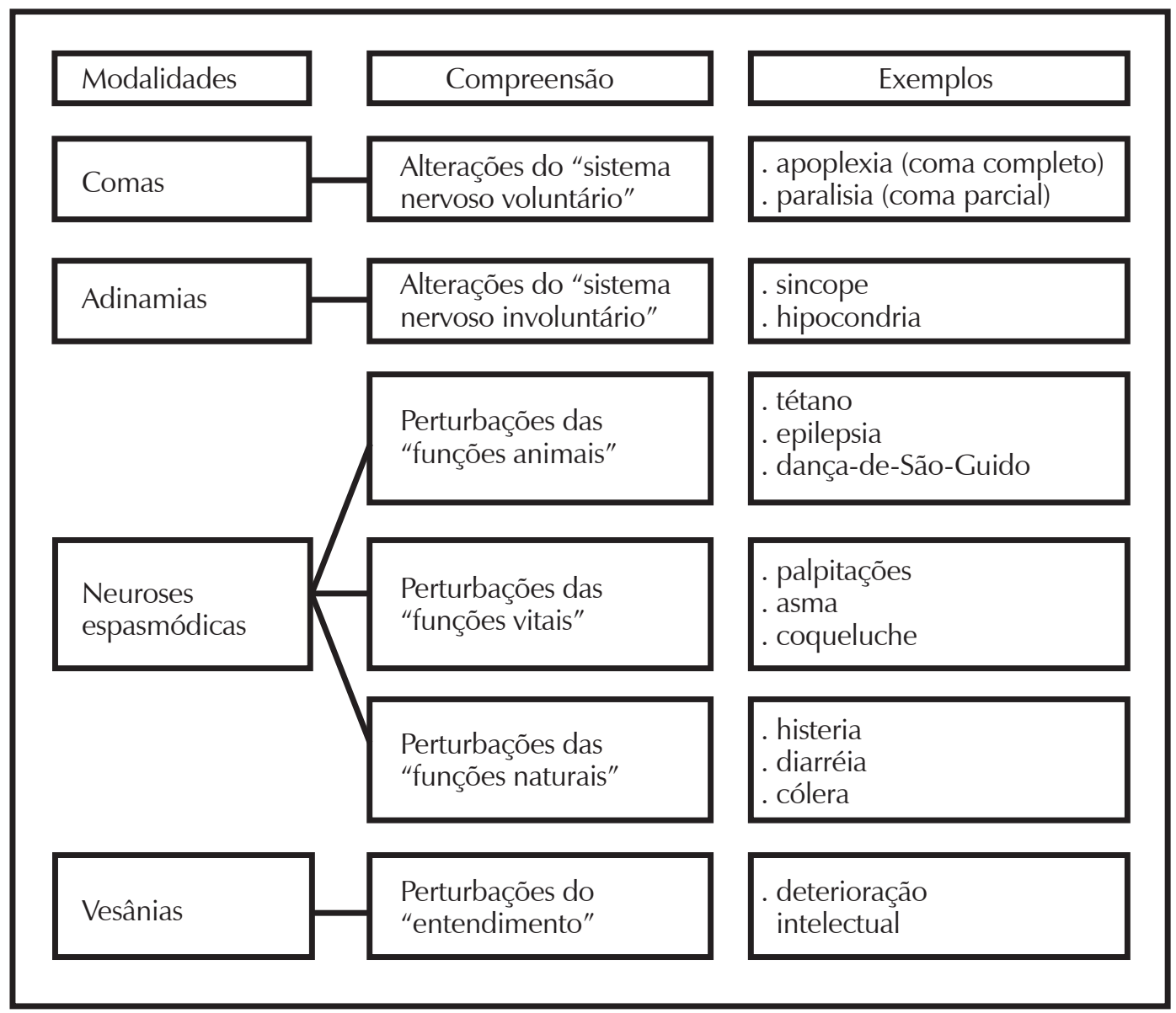

Fontes: Franz Alexander e S. T. Selesnick, História da Psiquiatria, BRASA, São Paulo, 1966; Y. Pélicier, História da Psiquiatria, Publicações Europa-América, Lisboa, 1973. 
Quadro 9

Philippe Pinel: Classificação das neuroses (1798)

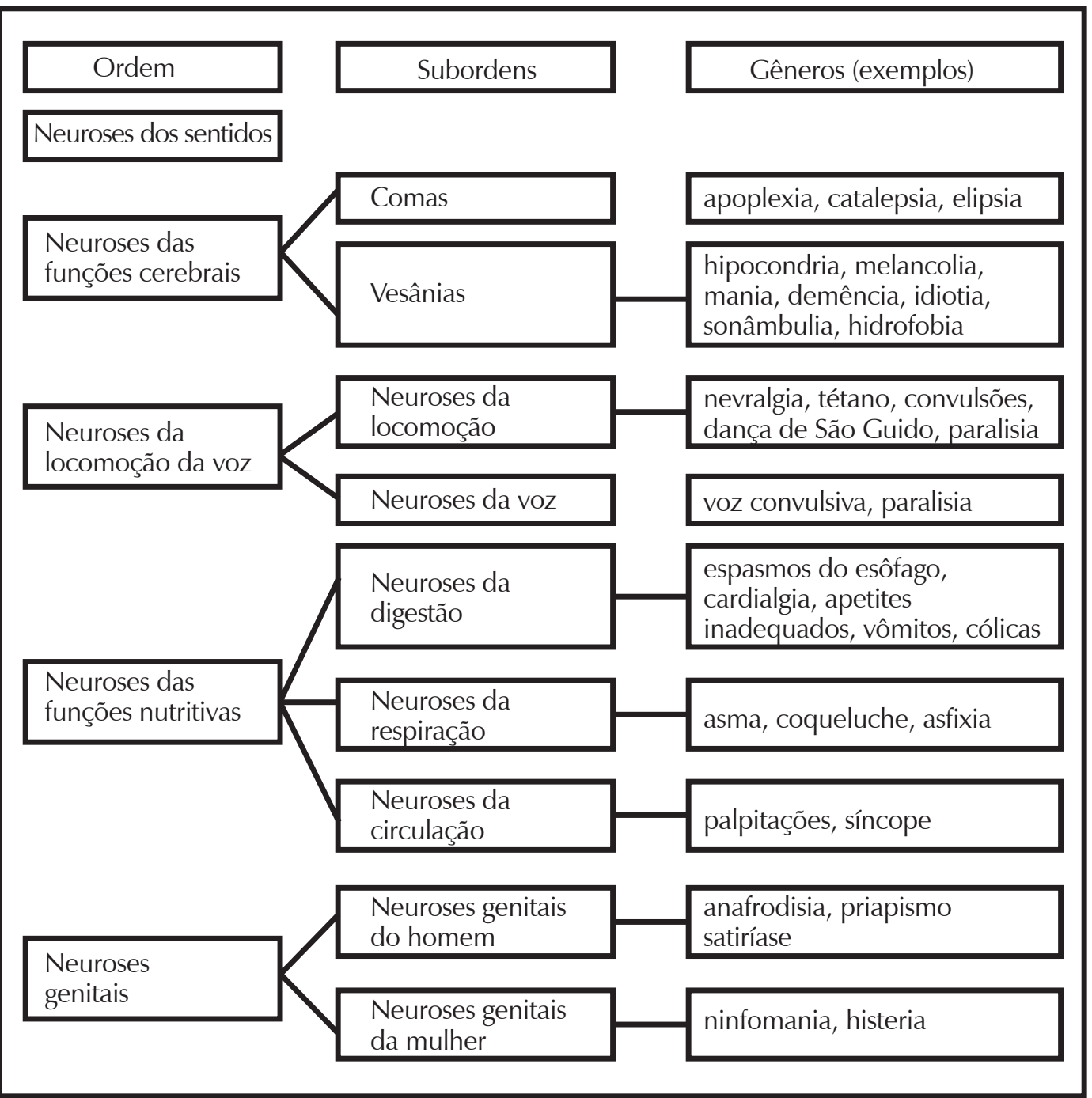


A tendência nosológica persistiu. Sagar, Robert Whytt, William Battie, E. C. Spitzka, Esquirol. . .

Não negarei a importância quase diria "disciplinar" da construção de classificações pela ciência. De classificações das ciências e de classificações dos fenômenos, problemas ou tópicos de uma ciência ou de uma parte relevante de uma ciência. Mesmo porque uma classificação verdadeiramente bem construída e eficaz supõe o domínio conceituai de seus elementos, pelo menos do ponto de vista operacional. Ora, tal não acontecia com os autores que, naquele tempo, tentavam ordenar as doenças mentais em sistemas lógicos e cientificamente conseqüentes. Em primeiro lugar, porque o conhecimento acumulado a respeito do tema era ainda por demais fragmentário e as relações mal estabelecidas. Em segundo lugar, porque a própria técnica de observação empregada era ingênua.

Para os classificadores, salienta Michel Foucault (1977, pp. 32 e ss.), "o ato fundamental do conhecimento médico era estabelecer uma demarcação: situar um sintoma em uma doença, uma doença em um conjunto específico e orientar este no interior do plano geral do mundo patológico." As observações eram realmente efetuadas. Mas sem controle, terminavam por levar a um "sistema de coincidências, indicando uma trama causai e sugerindo também parentescos ou novos encadeamentos entre as doenças".

Embora os limites e propósitos deste ensaio não justifiquem o exame minucioso das focalizações psiquiátricas dos séculos XVIII e XIX, em face de seu volume e amplitude, uma visão de conjunto se impõe, para ser possível uma reflexão final que leve em conta o "legado da psiquiatria tradicional".

Em uma obra que reúne uma amostra dos mais importantes textos sobre o assunto e no período em estudo, Mark D. Altschule (1976) distribui as contribuições relacionadas em dois grandes grupos:

. o primeiro abrangendo trabalhos teóricos concernentes a aspectos gerais da psicopatologia; . o segundo compreendendo a descrição empírica de síndromes.

Na exposição deste tópico acompanharei a organização geral do trabalho de Altschule, sem me prender obrigatoriamente a seu pensamento e estabelecendo as alterações que me autorizar o conhecimento de outras fontes ou a tanto levado pelo modo pessoal de encarar o assunto.

\section{Estudos teóricos}

De início, ressaltarei entre os estudos teóricos os voltados para o significado do pensamento psicótico. Como lembra Altschule (1976), Locke, ainda no século XVII, advertira no Essay Concerning Human Understanding que a produção verbal do psicótico, quando examinada cuidadosamente, revelava-se com sentido. Embora alguns autores tenham tangenciado a questão, somente com François Leuret (1797-1851), em 1834, e Ernst von Feuchtersleben 
(1806-1849), em 1845, foi o problema tocado de modo direto, salientando o primeiro a "lógica do pensamento psicótico" e o segundo, a possibilidade de a menta enferma se exprimir a si mesma "por meio de uma linguagem figurada".

Um segundo foco de interesse concerne ao inconsciente e às manifestações inconscientes da sexualidade.

No século XIX a idéia de inconsciente estava amplamente divulgada - embora se tivesse do inconsciente idéia nem sempre consentânea com a que seria posteriormente desenvolvida por Sigmund Freud. Fisiólogos e físicos, como Helmholtz, falavam de "inferência inconsciente" na percepção. Filósofos, entre os quais Beneke (1798-1854), Schopenhauer (1778-1841), Carus (1798-1869) e Ed. von Hartmann (1842-1906) especularam sobre o assunto. Nos limites da medicina, Étienne Georget (1795-1828), Friedrich Gross (1768-1852), Johann Christian Heinroth (1773-1843), Wilhelm Griesinger (18171868) e Henry Maudsley (1835-1918) reconheceram a existência de "forças fisiológicas" de que o homem não teria consciência. Heinroth, em particular, escrevia intuitivamente sobre o "conflito interior", distinguindo haver três níveis nos processos psicológicos (cf. Alexander e Slesnick, 1966, pp. 194-196):

a) forças instintivas e sentimentos, cujo objetivo é o prazer;

b) o ego ("ich"), que se caracteriza pela "autoconsciência"; é orientado pelo intelecto e tem por objetivo "a segurança em relação ao mundo exterior" e o "gozo da vida";

c) a consciência.

Além disso, acrescentava Heinroth ser a "consciência do pecado" a causa principal das perturbações mentais e haver uma "força mais alta", o supernós ("über-uns"), de orientação altruística, em conflito com o ego, "basicamente egocêntrico".

De outra parte, a suposição de que a sexualidade — não necessariamente o erotismo — fosse um dos fatores determinantes de perturbações mentais ou da conduta estava já presente em Galeno, reaparecendo em Ambroise Paré e em Robert Burton, respectivamente nos séculos XVI e XVII. Cabe, ainda, questionar se não estaria implícita na imagem social da histeria, interpretada pelo Malleus Maleficarum, se a fantasia de súcubos e de íncubos não teria muito a ver com tudo isso.

De qualquer modo, no século XIX esta relação saberia a uma redescoberta. Em texto de 1802, Cabanis (1956, I, pp. 272-315) dissertou longamente a respeito da "influência dos sexos sobre o caráter das idéias e das afecções morais" dos indivíduos. E em sucessivos documentos (cf. Altschule, 1976, pp. 25-33) von Feuchtersleben, Dickson, Georget, Maudsley e Donkin fortaleceriam a hipótese. Poucas foram então as vozes discordantes: M. Ryan é uma delas, conforme se apresenta em Lectures on Population, Marriage and Divroce as Questions of State Medicine, obra publicada em 1831.

A especulação sobre o inconsciente reforçaria o interesse pelo estudo sobre a natureza do ego e "personalidades múltiplas". Numerosos filósofos tinham focalizado a realidade e consciência 
do "eu". William James consagraria todo o capítulo X de seus Princípios de Psicologia — isto em 1890 - ao estudo do "self" (que definiu como a soma total de tudo o que um homem pode chamar de seu). James citou com insistência os Princípios de Fisiologia Mental, de W. B. Carpenter em relação ao hábito. Entretanto, naquela obra Carpenter examinara igualmente o ego. Tema focai de importantes passagens de Willis, Heinroth, Broussais, Griesinger, Meynert, Romberg, Maudsley e Spitzka, a nova concepção psicológica do ego, o "ego do fisiologista mental", diria Feuchtersleben compreendia uma realidade única, uma totalidade mente-corpo e se opunha à explicação metafísica, de "uma abstração espiritual da personalidade".

A antiga hipótese da "dupla" ou "múltipla personalidade", associada à idéia de intervenção do demônio, os especialistas que no século XIX investigariam o assunto (Wigan, Dendy, Holland, Spitzka, Janet) contrapuseram uma análise mais racional: Janet, sobretudo, fez colocações conseqüentes.

Dentro ainda das considerações teóricas relativas à psicopatologia desenvolvidas no século XIX, destaca Altschule mecanismos primários e sintomas, tais como ansiedade, comportamento anti-social, regressão e alucinações. O estudo das alucinações é feito quase sempre em relação às ilusões e delírios (Crichton, 1798), esforçando-se alguns por estabelecer as distinções entre esses conceitos (Esquirol, 1838; Spitzka, 1883) ou discutir sua experiência por parte de pessoas normais (Maudsley, 1867; Haslam, 1809). Haslam, em Observations on Madness and Melancholy, relacionou o sonho à "insanidade" e dissertou sobre as alucinações hipnagógicas: é clássica a diferenciação de Esquirol entre alucinação ("impressão sensória relativa a objetos inexistentes") e delírio ("impressão falsa, baseada na má interpretação de um estímulo sensório real").

Uma outra relação sugestiva é feita entre a alucinação e o efeito de drogas: já em 1817 há documentos a este respeito, e J. Moreau Le Tours escreveu em 1845 um ensaio considerado por muitos como notável, intitulado Du hachisch et de l'aliénation mentale. Os trabalhos nessa linha se multiplicariam: Baillarger descreveria as alucinações e delírios sob efeito de bebidas alcoólicas; Thomas Sutton (1767-1835) descreveria em 1813 o "delirium tremens"...

Afastando-me do esquema de Altschule, chamo a atenção para as tentativas, em princípio opostas, de explicação teórica das doenças mentais. De um lado, encontra-se o modelo da psicossomática (expressão utilizada pela primeira vez por Johann Christian Heinroth, em 1818 (cf. Alexander e Selesnick, 1966, p. 195). A atitude psicossomática era, entretanto, mais antiga — pode ser identificada pelo menos a partir de 1803, quando Johann Christian Reil (17591813) publicou suas Rapsódias sobre a aplicação da psicoterapia a perturbações mentais. Reil, aliás, foi o primeiro a empregar a palavra psiquiatria: "psiquiateria", chamava (cf. I. Veith, 1973, p. 182). O comportamento terapêutico de J. C. Reil era algo insólito. Conforme narram Franz Alexander e Sheldon T. Selesnick (1966, pp. 187-190), entre as recomendações terapêuticas de Reil incluiam-se: provocar ruídos (como o tiro de um canhão) para os silenciosos ou silêncio e escuridão para os excitados; proporcionar prostitutas para os rapazes com problemas de ordem sexual; "tortura não perniciosa", como a intimidação; representações teatrais, quando os pacientes eram acusados e julgados por seus defeitos e pecados e experimentavam sentimentos de culpa, hostilidade e medo. Além da "terapia teatral", acima referida, Reil propôs duas outras, com inegável sabor moderno: a ocupacional e a musical. Alexander Haindorf (1782-1862), 
enquanto defendia ser o organismo uma unidade psicobiológica, e Ernst von Teuchtersleben, para quem a psicoterapia seria "uma segunda educação", reforçariam a tendência psicossomática no século XIX.

De outra parte, cabe enfatizar o modelo neurológico que em última análise reduzia a lesões cerebrais ("cerebrias", na expressão de Scipion Pinei) ou a anormalidades sofridas pelas células do cérebro, a origem de todas as enfermidades mentaís. Dava-se, assim, continuidade às colocações de Charles Le Pois, e que teriam o apoio de somatistas de prestígio, como Henry Maudsley, Karl Westphal (1833-1890) e Carl Wernicke (1848-1905).

\section{Síndromes}

Sintomas, como os citados nos parágrafos anteriores, nem sempre foram estudados isoladamente. O reconhecimento de síndromes, favorecido pela tendência classificatória, ultrapassaria as noções de "estranheza" ou "excentricidade", dos primeiros tempos, e possibilitaria o exame de problemas bem mais representativos.

A depressão, por exemplo, para me fixar nos séculos XVIII e XIX, foi objeto da reflexão de número expressivo de especialistas da época. De uma nomenclatura inicialmente um tanto anárquica, quando as relações estabelecidas eram ainda confusas em face de outras "desordens" da afetividade, chegava-se a um conjunto de fontes, depoimentos pessoais, observações médicas e especulações, que poderiam ser metodologicamente discutíveis, mas representavam sem dúvida uma contribuição valiosa e conseqüente.

Muitas vezes foi associada à hipocondria: R. Blackmore (1726, A Treatise of the Spleen and Vapours; or Hypocondriacal and Hysterical Affections) distinguiu a "depressão neurótica" ou hipocondria, da "depressão psicótica" $(*)$ ou melancolia. Cheyne também assim o fez, dentro do estudo sobre a "doença inglesa", já mencionado no tópico anterior. Em 1828 G. M. B urro ws (Commentaries on the Causes, Forms, Symptoms, and Treatment, Medicai and Moral of Insanity) admitia ter conhecido pessoas inteligentes, mas nervosas, que se tinham tornado hipocondríacas apenas por terem lido livros médicos - e citava, como exemplos, entre outros, o "unhappy vapourer" J. J. Rousseau. Aliás, o tema da leitura tomada como um dos fatores determinantes de comportamentos neuróticos ou psicóticos foi então abordado com certa insistência. Robert Whytt, por exemplo, escreveria ainda no século XVII:"...história s lúgubres ou emocionantes, espetáculos de horror, um grande desgosto, uma grande cólera ou terror, e outras paixões, ocasionam por vezes os mais violentos e os mais repentinos sintomas nervosos" (cf. I. Veith, 1973, p. 164). Crenças quase mágicas sobre a influência do Werther e o "spleen" originado do romantismo, que em Álvares de Azevedo é quase documento, são alguns dos inúmeros

*A diferenciação entre neurose e psicose seria retomada de modo mais trabalhado por von Teuchtersleben. exemplos de suposições similares. Por sinal, em trabalhos mais recentes, autores como Fredric Wertham, parecem reabrir o debate, ampliando o sentido dessa influência a outros meios de comunicação (Wertham, 1956, 1949, 1954).

Entendida como melancolia - modalidade masculina da histeria - , a depressão encontrou em Haslam (1809), Krafft-Ebing (1893), Burrows (1820), Esquirol (1838), Griesinger (1845) e 
*O termo

"esquizofrenia" foi mencionado pela primeira vez por Bleuler (18571939), em 1911 (cf. Noyes e Kolb, 1974. p. 414).
Kraepelin (este já na passagem para o século XX), e no clássico depoimento de Burton, várias vezes aqui referido, penetrantes e historicamente importantes análises e interpretações.

Boerhaave (1709) falara do "amor da solidão". J. Guislain (1852) sustentara que todas as "frenopatias" seriam, fundamentalmente, variações da depressão. No entanto, duas outras relações parecem sobremaneira relevantes. Em primeiro lugar, a que envolve o conceito de mania e a noção de psicose maníaco-depressiva, já esboçada por Théophile Bonet no século XVII — Bonet falava em 1679 da "melancholiae mania" e, em 1686, do "maniaco-melancholicus" (cf. Altschule, 1976, p. 139). Em segundo lugar, a descoberta dos estados alternantes entre a depressão e a elação. O fato é apontado por vários autores, entre os quais R. Mead (1755), Jean-Pierre Falret (1854, "folie circulaire"), Jules Baillarger (1843, "folie à double forme") e Karl Kahlbaum (1874, "ciclotimia", termo absorvido pelo vacabulário técnico posterior). Kahlbaum propôs ainda chamar de "catatonia" a uma enfermidade que situava entre as patologias do pensamento e, como tal, fora descrita anteriormente por Guislain (1833), Gooch (1859) e Griesinger (1845).

As "desordens esquizo-afetivas" são tratadas por Georget, em 1820 ("obtusidade"), Griesinger, em 1845 e J. Luys, em 1881. Jules Baillarger, em 1843, pretendeu que a "obtusidade" descrita por Georget seria na maioria das vezes aparente. Em sua opinião seria com freqüência acompanhada da idéia de suicídio e corresponderia ao "grau mais severo de uma modalidade de melancolia". Sugeria, ainda, Baillarger, existir uma analogia entre o sonho e a "obtusidade".

Entretanto, a primeira descrição da esquizofrenia - embora sem mencionar o nome $(*)$ — foi feita por J. Haslam, em 1809 (cf. Altschule, 1976, pp. 222-223). De modo geral, os historiadores da psiquiatria indicam a demência precoce como o ponto de partida para o estudo da esquizofrenia: era justamente dentro deste contexto, da "hebefrenia" que Haslam pensava. Note-se, contudo, que o termo hebefrenia é devido a Ewald Hecker (1843-1909), que em 1871 a distinguiu da "deterioração mental"; enquanto Benédict Morel (1860, Traité des Maladies Mentales) falaria de "demência precoce". Morel pensava em "degenerescência", idéia que Valentin Magnan (1835-1916) retomou para diferençar o que chamou de "níveis de degeneração": a inferior (idiota e imbecilidade); a média (debilidade); e a superior (quanto é desarmonioso tanto o desenvolvimento intelectual quanto o moral).

A literatura sobre a "demência" é volumosa e diversificada. Além dos autores já mencionados, outros, como Guislain, Conolly e Dickson aclarariam aspectos determinados da questão. Esquirol chamara a atenção, desde 1838, para a "demência senil". Em 1890, Charpentier, em trabalho apresentado ao "Congresso Anual de Medicina Mental", realizado em Paris, emprestava um sentido muito amplo ao conceito de demência precoce, abrangendo forma psicopatológica do comportamento infantil ou adolescente (cf. Altschule, 1976, p: 232). Por sua vez, Kraepelin apresentaria no seu Lehrbuch der Psychiatrie clássico texto sobre o tema, definindo a demência e distinguindo suas formas hebefrênica, catatônica e paranóide.

Por sinal, também a paranóia foi de início compreendida de acordo com padrões diferentes dos atuais. Era a expressão empregada para designar genericamente qualquer estado psicopatológico. Até que, já em 1863, Karl Kahlbaum sugeriu que tivesse seu emprego limitado aos estados 
persecutónos e delírios de grandeza (*). Embora sem utilizar a palavra paranóia, Haslam havia abordado o assunto (1810), enquanto Lasèque (1816-1883), em 1852, e Morel, em 1860, discutiram o "delírio de perseguição" (folie systématisée). Lasèque tratou ainda problemas correlatos, como a "loucura a dois" e o "roubo ostensivo".

Dando continuidade ao acompanhamento da estrutura geral da exposição de Altschule, lembro os estudos realizados sobre as chamadas "desordens nervosas", com ênfase no conceito de "neurastenia", desenvolvido por G. M. Neard em 1869 e rapidamente popularizado. Já no início do século XIX, em 1903, P. Janet elaborava minuciosa análise das "psicastenias".

A histeria, várias vezes referida nos tópicos anteriores, foi examinada no século XIX em textos clássicos de Ryan, Laycook (1812 - 1876), Bricquet, Charcot e Janet — antecedendo e já quase contemporâneos, alguns contemporâneos de Breuer e Freud.

John A. Jackson (1835-1911), o "pai da neurologia clínica", concebeu a idéia de que uma descarga anormal de energia na córtex cerebral deveria ser a causa da epilepsia (cf. Noyses e Korb, 1974, p. 302).

Sem dúvida, a exposição acima não cobre toda a temática analisada pelos psicopatologistas do século XIX. Entretanto, penso, é suficiente para os propósitos deste ensaio. Mostra a amplitude e deixa entrever a fragilidade metodológica das observações médicas que a fundamentam. A fragilidade e o imponderável do "olhar", como diria Foucault (1977, p. vii).

\section{CAPITULO III}

\section{Onde se fala das incertezas da introspecção e das vicissitudes da observação objetiva}

Como se vê, no início do século XX defrontava-se a psicologia acadêmica com uma embaraçosa situação que the era imposta pelas insuficiências do método introspectivo, utilizado em suas investigações. No plano aplicado, da psicologia clínica que se esboçava, a realidade não era menos incerta, em referência aos cânones da ciência positivista. Afastando-se da especulação filosófica, não encontraria um lugar definido entre as ciências. Claude Bernard (1963) publicara em 1856 uma Introdução ao Estudo da Medicina Experimental, defendendo com veemência a aplicação do método experimental pelas ciências médicas. Abrindo mão do método experimental, a medicina deveria abrir mão também de suas pretensões científicas e limitar-se a ser arte, construída sobre o senso comum ou sobre instáveis rasgos de genialidade de pensadores médicos bissextos. O quadro que se oferecia à psicologia era pelo menos similar. Suas pretensões científicas não poderiam ir muito longe, quando o método empregado em suas investigações era essencialmente subjetivo.

*Alguns autores indicam o ano de 1878 em lugar de 1863 como o da apresentação formal do pensamento de Kahlbaum. Quando as técnicas que começava a trabalhar em suas aplicações clínicas eram originadas de uma herança psiquiátrica sem maior consistência metodológica, nos termos da ciência positiva que se impunha então como modelo científico único.

Este, o problema. Parecia tão evidente, que seria uma temeridade discuti-lo. 
*Wundt fundara formalmente o primeiro laboratório de psicologia experimental em Leipzig, em 1879. Watson assim se referia em 1912 um pouco mais de trinta anos após..
A solução que aos poucos ganhava corpo chegou afinal a ser tão indiscutível quanto a realidade do problema em questão: no plano acadêmico, a psicologia deveria abandonar a introspecção, como outrora abandonara a metafísica - urgia fazer-se objetiva. No plano aplicado, apresentava-se como indispensável desistir dos esquemas vigentes, de observações sem controle, de interpretações qualitativas, para adotar um modelo quantitativo, com base em mensurações, capaz de informar a compreensão do caso individual. Também a psicologia aplicada — era a tendência predominante — urgia fazer-se objetiva.

\section{A crítica da introspecção}

Seria injusto deixar de reconhecer o esforço desenvolvido pelos psicólogos, a partir dos primeiros anos do século XX, no sentido de encontrarem uma metodologia adequada ao problema em estudo e que ao mesmo tempo correspondesse ao que preceituava a ciência vigente. O primeiro passo concreto compreendeu uma atitude crítica em face da introspecção. As incertezas do método introspectivo são realçadas de modo conseqüente e quase ansioso. É uma posição então generalizada, apesar de apoiada em diferentes filosofias da psicologia.

Sem favor, coube ao behaviorismo assumir de modo mais radical a liderança do combate às insuficiências do método introspectivo. Na verdade, este é um dos polos da "batalha do behaviorismo".

Entendia Watson que a psicologia introspectiva teria tido uma origem religiosa e atribuía ao método introspectivo os "trinta anos estéreis do laboratório de Leipzig" (*). Em outras palavras: reconhecia na introspecção uma disciplina subjetiva e inútil para a ciência, cujo exercício teria um sentido apenas moral ou religioso, quando muito gerando mitos e não, fatos. Incisiva e inteligente, a crítica de Watson é prejudicada por sua linguagem e por certa leviandade com que a associa à crítica de outras correntes do pensamento psicológico, à maneira do funcionalismo e do gestaltismo, os quais considera como "filhos ilegítimos da introspecção".

A atitude contrária ao método introspectivo é adotada pelos behavioristas, como um princípio de coerência mínima com o pensamento da escola. Atitude que se manteve intacta através das várias gerações de behavioristas. Tolman, por exemplo, em seu artigo de 1922 para a Psychological Review sobre uma "nova fórmula para o behaviorismo" (1951, p. 1), apesar de toda abertura de seu "behaviorismo intencional", reconhecia que "desde os dias do experimentos de Ebbinghaus sobre a memória, tornou-se cada vez mais óbvia a inadequação do método meramente introspectivo".

A psicanálise reagiria com igual veemência contra a introspecção. As razões de Freud são, no entanto, bem outras do que as correntes entre os behavioristas. Georges Politzer (1969, pp. 7398), que analisou a questão em texto clássico, ressaltou que Freud se opôs à introspecção por seu caráter de abstração, pela generalidade a que pretende chegar, pela função interpretativa do sujeito-psicólogo. Freud preferia o relato através da associação livre, possibilitando o projeto da "psicologia concreta" (Politzer), preferia a objetividade do informe, cuja interpretação ficaria sob a responsabilidade do analista e não do sujeito experienciante, como acontecia com o 
introspeccionismo. De fato, a introspecção como método da psicologia — não o comportamento introspectivo - elimina qualquer possibilidade de psicanálise.

Tampouco o gestaltismo admitiu a introspecção, nos moldes em que vinha sendo praticada pela psicologia do século XIX e pelos experimentalistas de Titchener no século XX. Coerente com sua visão do mundo e do homem, e psicologia da gestalt combateu na introspecção sua tendência elementarista e artificial.

É verdade, escrevendo em 1928, Hohler (1948) defendeu ostensivamente a exploração da "experiência direta" pela psicologia, como fez questão de dizer, sem pedir desculpas ao behaviorismo. Contrariando Watson, sustentou Kohler ser a experiência direta a matéria prima da psicologia. Entretanto, reconheceu ter um valor limitado, prevendo a sobrevivência de apenas algumas partes da experiência direta, quando o desenvolvimento da psicologia possibilitar a "grande limpeza". Para Kohler, representando o pensamento gestaltista, seria injusto considerar "irreais" as descobertas dos introspeccionistas. Apesar disso, são incompletas e constituem um perigo para o progresso da psicologia, por julgarem suas presunções como conclusões, quando a psicologia, sendo uma ciência jovem, tem seu futuro na dependência de "descobertas de que nem suspeitamos até agora". Neste sentido, pensa Kohler, o behaviorismo é tão conservador quanto o introspeccionismo. Para a psicologia da gestalt o reducionismo sensorial do introspeccionismo, conduzindo a uma concepção psicológica de elementos, não poderia jamais corresponder a uma compreensão satisfatória de cada situação total, explicável a partir da experiência perceptiva.

O método introspectivo, tal como foi praticado, representaria a impossibilidade de todo o projeto gestaltista - obstáculo plenamente sentido por seus principais teorizadores. Seria de se esperar a crítica e a rejeição, como, de fato, aconteceu.

Como se vê, no início e durante pelo menos toda a primeira metade do século XX a introspecção, como método da psicologia, foi combatida pelas correntes psicológicas mais expressivas — ainda que apoiadas em tão diferentes conjuntos de princípios.

De outra parte, logo os compêndios absorveriam e fariam lugares comuns certas obviedades de que a introspecção dificilmente teria meios de se defender. Jolivet (1947, 11, pp. 26-28), tomado como exemplo, sintetizou os "argumentos contra a introspecção", à maneira de muitos outros da época:

a) seus limites - experiências tais como uma emoção forte ou ,os sonhos não podem ser objeto de observações pelo próprio sujeito, no momento em que se desenrolam;

b) o jogo da interpretação, a qual é conduzida "inconscientemente" por sentimentos e idéias;

c) e a insuficiência dos meios de controle.

Os limites da introspecção como método se ofereceram como amplo alvo para as críticas: nem as crianças, nem os adultos não treinados poderiam ser objeto de estudo psicológico. Além disso, 
há insistentes advertências de que toda introspecção - e não apenas nos casos de emoções fortes ou de sonhos - em última análise consistiria em retrospecção.

Entendo serem legítimas as restrições impostas à introspecção, como método da psicologia, método que pretendeu ser científico e experimental. Cabe agora identificar e avaliar as soluções propostas em seu lugar.

\section{Para a construção de uma metodologia psicológica objetiva}

A solução apontada no século XX por todos os sistemas bem sucedidos pode ser resumida em uma palavra: objetividade. Todavia, há importantes divergências quanto à definição operacional do que deve ser admitido como objetivo.

No caso da psicologia acadêmica, a promessa maior vinha, de um lado, da psicologia animal e comparada, de inspiração darwiniana, e, de outro, da psicologia fisiológica - menos do modelo wundtiano do que do originado da reflexologia, na versão russa do século XIX.

No caso da psicologia aplicada, a objetividade era prometida pelos "testes mentais", nascidos da psicologia diferencial, à Galton e à James Mckeen Cattell, também eles de inspiração darwiniana, trabalhados por Binet e depois, por Piéron - entre outros - , cujo tratamento quantitativo seria refinado com base na teoria de Spearman, proposta em 1904.

Além disso, Ribot oferecia uma alternativa psicopatológica, que se filiava à tradição da psiquiatria clássica.

Havia um problema, sim. Mas havia uma solução para o problema. Ou parecia haver. Objetividade: uma palavra quase mágica, que ajudava a superar o sentimento de inferioridade dos psicólogos em face dos demais cientistas e parecia abrir a porta que daria acesso ao saber científico. Mas, o que representava a objetividade para os opositores do introspeccionismo?

No contexto psicanalítico, de acordo com a interpretação de Georges Politzer (1969, 1973), a objetividade é representada antes de tudo pelo relato obtido através da associação livre. Sem fugir ao compromisso intencionalmente assumido por seu projeto, de explicar a personalidade, de alcançar o mais profundo da experiência subjetiva, a psicanálise atua a partir do discurso do sujeito. O relato é concreto e, em certo sentido, é o "fato" com que trabalha o analista. Portanto, a proposta psicanalítica é fundamentalmente empírica.

Não obstante, é prejudicada como projeto científico pois, em primeiro lugar, a coleta do informe é realizada sem que se busque um controle rigoroso das variáveis; em segundo lugar, sua análise e sua interpretação, conforme o modelo até hoje vigente, são subjetivas - embora o analista seja treinado para reduzir o efeito de sua própria maneira de ver o mundo, e tenha como referência um conjunto de princípios analógicos gerais, internamente coerentes; em terceiro lugar, a construção do discurso teórico da psicanálise conservou até o momento os inconvenientes e as insuficiências das descrições e teorizações clínicas dos séculos anteriores, apoiadas em observações casuísticas o que, de resto, aplica-se a toda a psicologia clínica atual. 
Para o gestaltismo, a objetividade é igualmente assegurada pelo relato, neste caso, a partir da experiência direta do sujeito. Reconhecendo ser a psicologia uma "ciência jovem", admitiu Kohler (1948) - ponto sobre o qual voltou a insistir Koffka (1953) — seu estágio de disciplina em construção, com importantes possibilidades futuras, embora, no momento em que escreviam (Kohler, em 1928; Koffka, em 1935), se encontrasse ainda muito distante de suas metas.

Pensavam os gestaltistas em um modelo semelhante ao da física para a psicologia, obedecendo a uma idéia básica de campo, onde o comportamento é compreendido em termos dinâmicos, em contraposição a qualquer modalidade de mecanicismo, cartesiano, associacionista ou behaviorista. Apesar de enfatizarem a fisiologia, evitaram a tentação reducionista - o conhecimento fisiológico é servo e não patrão da psicologia. Defenderam a necessidade de experimentação e mensuração, mas não quantificaram os dados obtidos. É verdade que entre as obras mais representativas do gestaltismo, de Kohler (1948), Koffka (1953) e Wertheimer (1959), somente a segunda consagra alguma atenção à personalidade. Contudo, há uma implícita tendência personalista na focalização dinâmica do comportamento, no quadro espaço-temporal único que define o campo, no reconhecimento do todo como uma realidade diferente das partes que o compõem, na distinção entre a realidade aparente e a fenomenológica.

O projeto gestaltista original, assim como o freudiano, apresentou-se insatisfatório quanto ao controle na coleta dos dados e discutível, quanto a seu tratamento. Mas representou uma fecunda abertura e reexames teóricos — o que foi explicitamente admitido por Hohler e Koffka.

J. B. Watson, principal opositor da introspecção, foi, igualmente, o principal construtor de uma proposta metodológica objetiva para a psicologia.

O associacionismo fora um mecanicismo e, como tal, a primeira esperança mais concreta com que trabalhara o psicólogo, no século XIX. A reflexologia (Séchenov, Bechterev, Pavlov), indicava o caminho que psicologia deveria trilhar para se fazer objetiva. $\mathrm{O}$ associacionismo, a reflexologia e a pregação inicial de Piéron eram acenos que pareciam mudar o rumo e esquecer o passado.

Disse "pregação" inicial de Piéron e entendo e que este é bem o termo para designar os sucessivos artigos e conferências envolvendo direta ou indiretamente o assunto. A partir da memorável conferência pronunciada na École Pratique des Haiires Études em 1907 e no ano seguinte publicada pela Revue du Mois (Piéron, 1958, I, pp. 3 e ss.); "L'ávolution du psychisme et l'étude objective du comportement". Naquela oportunidade - e relembro o ano, 1907 - sustentava Henri Piéron que o programa da psicologia deveria incidir sobre "a atividade dos seres e suas relações sensório-motoras com o meio". E insistia: “...sobr e aquilo que os americanos chamam de Behavior, os alemães das Verhalten, os italianos lo comportamento e sobre o que nós (franceses) temos o direito de chamar le comportement dos organismos".

Descartes admitira um dualismo que possibilitava a existência de duas psicologias: a psicologia como ciência natural (res extensa), explicável mecanicamente e passível de estudo pelos métodos das ciências naturais; e a psicologia como ciência do espírito (res cogitans), a qual não poderia ser explicada deterministicamente e seria estudada através da especulação, de cunho introspectivo. A distinção é cômoda, camufla importantes questões e, de modo mais ou menos 
aproximado, foi aceita por alguns teóricos do século XX, como é o caso de Spranger. Contudo, esta não é a posição mais comum no século XX, quando o artificialismo da distinção cartesiana foi sentido de maneira eloquente pela maioria dos psicólogos — se bem que muitos entre eles não pareçam ter consciência disto. A psicologia como ciência do espírito foi rechaçada como excrescência metafísica, quando muito admitida como integrando o "longo passado" a que se referia Ebbinghaus (1910, p. 1), abrindo sua Introdução à Psicologia. Apena; uma parte do programa cartesiano - a psicologia como ciência natural - compreenderia a "curta história". Assim, ocupando um lugar entre as ciências biológicas, "menos por seu objeto do que por sua linguagem" (Piéron, 1958, I, p. 4), a única psicologia cientificamente possível seria afinal objetiva. Só os fatos diretamente observáveis interessariam ao psicólogo.

Dessa maneira, o método introspectivo estaria banido por completo: já não mais se faria a tentativa do "olho ver-se a si mesmo" nem se buscaria a o infrutífero "autodesmembramento do sujeito" em sujeito e objeto da experiência, como ironizara Comte (cf. Rubinstein, 1967, pp. 48:51).

Tudo parecia convergir para um pensamento, que Watson apreendeu muito bem e soube exprimir com rara felicidade. Apesar de sua curta passagem pela psicologia acadêmica, J. B. Watson seria o líder maior do movimento em prol de uma psicologia objetiva, a qual se apoiaria sobre o modelo S-R. Embora desde pelo menos 1912 trabalhasse sobre o assunto, a proposta formal de suas idéias (1973) surpreendeu pela precisão e por seu conteúdo polêmico. "O behaviorismo é vinho novo e não pode ser posto em odres velhos" - escreveria posteriormente (1972, p. 26).

A tarefa básica da psicologia objetiva foi, quer no modelo russo de Bechterev (1953), quer no modelo behaviorista, a partir das conferências pronunciadas por Watson em 1912 na Universidade de Columbia, sustentar que no estudo de comportamento humano deveriam ser aplicados os mesmos métodos experimentais e a mesma linguagem descritiva utilizados pelos investigadores que se dedicavam à pesquisa com animais inferiores. Como inevitável conseqüência, não apenas recusava Watson a psicologia metafísica, que reputava mitológica, como não reconhecia objetividade no experimentalismo de Wundt e de Titchener. Apesar de admitir que Wundt pretendesse uma psicologia objetiva, ironiza-o, como ironiza William James, pelo emprego que faz do termo "consciência". Escreveu (1972, p. 22): "Consciência, oh! sim, todosdevemos saber o que é esta consciência! E adiante: "A coisa que chamamos consciência somente pode ser examinada através da introspecção — uma olhadela sobre o que acontece em nosso interior..."

O essencial da proposta de Watson não está no termo "comportamento". O essencial se encontra na opção empírica e experimental de sabor galileano, ideologicamente neutra, concreta, geral, quando o individual é compreendido como um acidente historicamente condicionado' Neste caso, a psicologia será construída sobre "extrospecções" e tudo o que não for passível de extrospecção deverá ser abandonado. Só a observação externa é objetiva e, portanto, aceitável em termos científicos. De acordo com o novo programa, poder-se-ia dizer, parafraseando ironicamente William James (1955, p. 153), que o produto da introspecção, ou observação interna, fazendo sua aparição ante os umbrais da consciência, é uma entidade tão mitológica quanto o valete de espadas. 
Mas, como realizar a observação objetiva do comportamento humano? De acordo com a lei da parcimônia (cânone de Lloyd Morgan), de 1894, "em nenhum caso uma ação pode ser interpretada como a conseqüência do exercício de uma faculdade superior, se puder ser interpretada como o resultado do exercício de um nível inferior na escala psicológica" (cf. Boring, 1957, p. 474). Lloyd Morgan pensava nos termos da psicologia animal e contornava o antropomorfismo de Romanes. Mas deixava uma pista para se conceber a aplicação de métodos da psicologia ou da psicofísiologia animal à psicologia humana. Seguindo suas pegadas, a proposta de Watson é precisa e radical. "Creio", escreveu em 1913, "que podemos fazê-lo em poucos anos, sem nos precipitarmos na absurda terminologia de Beer, Bethe, von Uexküll, Nuel e das geralmente chamadas escolas objetivas. Pode ser feito nos termos de estímulo e resposta, nos termos da formação de hábitos, integrações de hábitos e assim por diante".

E "em poucos anos" Watson explicitava (1972, pp. 35-59) suas idéias sobre como estudar o comportamento humano. De início, esclareceria $(1972$, p. 23) entender por estímulo "qualquer objeto externo ou qualquer mudança nos próprios tecidos devida à condição fisiológica do animal" e por resposta, "o que o animal faz, como voltar-se para ou em direção oposta à luz, saltar ao escutar um ruído, ou as atividades mais elevadamente organizadas, por exemplo: edificar um arranhaceu, desenhar projetos, ter família, escrever livros, etc".

Assim, os problemas psicológicos podem ser equacionados, "por mais complexa que seja a situação", de conformidade a uma das seguintes alternativas:

1) Estímulo (S) dado $\rightarrow$ Resposta (R) a determinar
2) Estímulo (S) a determinar $\leftarrow$ Resposta (R) dada.

E conclui que o problema será resolvido quando tanto o estímulo quanto a resposta forem determinados.

O reflexo condicionado é o processo por excelência a ser usado na experimentação sobre a conduta. Mas outros métodos podem ser aceitos como objetivos, como os "testes mentais" e a "experimentação social".

Foi oportuna a crítica à introspecção. Uma "psicologia pura", preocupando-se quase tão somente - como no modelo estruturalista de Titchener - com o homem branco, adulto, civilizado e resistindo a qualquer aplicação prática, era insustentável.

São flagrantes as insuficiências da introspecção, como método exclusivo da psicologia. O conflito das interpretações, utilizando a feliz expressão de Paul Ricoeur (1969), seria um estéril conflito de personalidades, de percepções subjetivas, onde a opinião substitui a lei, a literatura substitui a ciência e a intuição, a técnica. Era o caos - tinha razão Watson.

Mas, teria razão Watson ao contrapor à introspecção, como única saída metodológica para a psicologia, um método objetivo, mas artificial, muitas vezes tão limitado em relação a certos temas psicológicos quanto aquele a que se opunha? 
Sem dúvida, entre todos os sistemas teóricos da psicologia, o behaviorismo é o que se apresenta mais próximo do modelo científico do positivismo. O que faz a psicologia mais se parecer com a biologia. Suficiente talvez para prever e manipular estímulos e respostas, dentro de uma margem às vezes elevada de acertos, nem sempre é útil para explicar e compreender o comportamento dos indivíduos.

Watson contestaria que o behaviorismo apenas se desvencilhou de antigos preconceitos que integravam a tradição social e literária da velha psicologia e de uma linguagem caótica, formada de termos subjetivos, levando a um "mar de contradições". Não convence. Seria resolver um problema descartar-se de seus aspectos mais difíceis?

Mais do que um estímulo, o que experimentamos em nossa experiência diária é a existência de situações extremamente complexas e irrepetíveis; mais do que um reflexo, uma resposta física e uniforme, o resultado consiste em um comportamento - e este comportamento, em sua originalidade, é que é preciso decodificar.

Em termos acadêmicos, parece fácil a defesa do behaviorismo — sobretudo a partir de Tolman. Contudo, a história tem suas leis e o problema que começava a desafiar os psicólogos no início do século XX é hoje ainda mais premente, pois se tornou mais agudo e não encontrou na psicologia acadêmica o tratamento cientificamente adequado. A história vem apontando as vicissitudes do método objetivo, o qual vem se revelando incapaz de responder a suas necessidades. Pois, como escreve David Bakan (1973, p. 94), a sociedade necessita de uma "psicologia mais apropriada a seus problemas".

E, na medida do possível, o psicólogo enquanto profissional vem suprindo com suas observações assistemáticas, suas inferências não raro duvidosamente empíricas, sua intuição subjetiva, ignorando os controles que o método científico impõe, as lacunas decorrentes da alienação ingênua do projeto que pretende ser científico da psicologia contemporânea.

Tinha razão Watson. Apenas, persiste o cáos.

\section{CAPÍTULO IV}

\section{O Dilema}

Toda prática profissional conseqüente supõe o domínio de um conjunto de técnicas construídas em referência a elaborações científicas coerentes e a uma filosofia pelo menos implícita. Assim, enquanto profissional, o psicólogo deve manipular técnicas, as quais, no seu caso, podem ser classificadas como de mensuração, diagnóstico, avaliação, orientação, psicoterápicas e persuasivas. A fundamentação científica e/ou a construção dessas técnicas deve, tomar como referencial um quadro de enunciados hipotéticos e empíricos coerentes entre si, metodologicamente válidos e, quando nada, consistentes interna e externamente.

Parece óbvio que as técnicas utilizadas pelo psicólogo na prática de sua arte de mensurar, diagnosticar, avaliar, orientar, curar e persuadir indivíduos, em princípio, não poderão ser 
construídas sem o apoio da psicologia acadêmica. Por conseguinte, cabe à psicologia acadêmica, entre suas metas fundamentais, a elaboração de um sistema teórico geral, hipotético e empírico, e de quantos subsistemas impuserem as grandes categorias da problemática pessoal e psicossocial identificadas no tempo. Em outras palavras: a elaboração de uma teoria geral da psicologia e de um conjunto coerente de teorias concernentes a importantes segmentos do comportamento ou da experiência, a áreas de problemas afins, a normas metodológicas de base.

A psicologia acadêmica assim construída possibilitaria por sua vez a construção de instrumentos de medida, diagnóstico, avaliação, assim como de técnicas de orientação, persuasão e terapia, cientificamente válidos.

Entretanto, o que aqui foi visto comprova que, longe de se desenvolver como um sistema confiável do ponto de vista científico, a psicologia acadêmica no início do século XX era como ainda hoje em grande parte o é, apesar de seus importantes avanços - uma "ciência muito insatisfatória" (Koffka). Além disso, pouco tinham a ver com a prática da psicologia: a única exceção legítima é a psicanálise - na verdade, o menos acadêmico dos sistemas e o mais frágil, do ponto de vista científico. A psicologia da gestalt e, sobretudo, o behaviorismo, geraram aplicações práticas — mas não responderam a todos os problemas que se puseram ao psicólogo. Originado do pragmatismo norte-americano, o funcionalismo alimentava inequívoca aspiração de favorecer a construção de instrumentos úteis de intervenção psicológica. Entretanto, o funcionalismo não foi muito além do que em 1907 James Rowland Angell (1907) reconhecia ser seu estado: "pouco mais do que um ponto de vista, um programa, uma ambição".

Não encontrando apoio na psicologia acadêmica convencional para responder de modo adequado aos problemas postos pela sociedade, o psicólogo vem desenvolvendo no curso do século XX uma psicologia paralela, casuística, que por vezes nem chega a ser introspectiva, limitando-se a uma reflexão sobre a experiência individual. E esta psicologia paralela, em cumprimento a um estranho paradoxo, vem conquistando - aliás, com justiça - o principal lugar na formação acadêmica dos novos psicólogos. Ao lado de uma reduzida literatura que se esforça por ser científica, no entanto divorciada dos problemas que logo terá a equacionar, por isso mesmo pouco atraente, o estudante entra em contato com uma literatura viva e atual, muito mais sedutora, mas construída sobre alicerces inseguros. Esta é a que o norteará na sua atividade profissional futura, enquanto aquela será esquecida. Ou — e aqui é ainda mais desconcertante o paradoxo - muitos, a maioria, talvez, entre os se dedicam à pesquisa em psicologia, sobretudo à pesquisa experimental ou teórica, sempre estiveram distantes dos campos de aplicação profissional. É mais cômodo apontar falhas e ditar normas do que as cumprir, do que se expor, do que expor suas idéias ao inflexível juízo da prática, "sujar as mãos" com a argamassa.

Tudo leva antes ao confronto do que à complementação.

O dilema da psicologia contemporânea coloca-se basicamente em relação ao modelo científico das ciências naturais, à metodologia da pesquisa física e biológica, que pretende absorver. Pode ser assim formulado:

- Desenvolver-se de acordo com a metodologia científica é se isolar da realidade dinâmica da experiência individual, do comportamento em sua totalidade; ora, a intervenção psicológica baseada em construções teóricas isoladas da realidade é inútil; 
- Abrir mão da metodologia científica é fundamentar a intervenção psicológica em um conjunto de intuições sem controle; ora, a intervenção psicológica fundamentada em intuições sem controle é igualmente inútil.

Será à psicologia inevitavelmente inútil? São as proposições acima verdadeiras? Bem. O comportamento da maioria dos psicólogos leva a supor que sim. Insisto: são verdadeiras as proposições acima? Penso que não. Trata-se a meu ver de um falso ou apenas aparente dilema. 0 erro básico entendo ter nascido com o dualismo cartesiano e se acentuado com a redução da psicologia ao status de uma ciência natural, com sua definição nos termos de uma ciência natural, que não é, que nunca foi.

Sim, muitos têm constatado que a ciência facilmente se divorciada realidade, facilmente se divorcia da vida. Koffka (1953, p. 40; 1975, pp. 34-35), um dos que defendem este ponto de vista, acrescenta: "O matemático necessita de uma fuga da tênue atmosfera de suas abstrações, por mais belas que sejam; o físico quer deleitar-se em sons macios, suaves e melodiosos, que parecem revelar mistérios ocultos sob a cortina de ondas e átomos e equações matemáticas; e até o biólogo gosta de desfrutar das cabriolas e folguedos de seu cão aos domingos, sem que o estorve a sua convicção dos dias de semana de que, na realidade, essas cabriolas nada mais são do que cadeias de reflexos mecânicos. A vida converte-se numa evasão da ciência, a ciência num jogo".

O caminho que se abre à psicologia não é o de se render à inevitabilidade de um falso dilema. Mas, o de repensar sua posição no concerto geral das ciências, o de reconhecer a singularidade de seu objeto e o de se redifinir metodologicamente. Nesse esforço de reconhecimento de sua,identidade e de suas funções, de sua estratégia de ação e de reconstrução metodológica (Bakan, 1973), nada deve ser desprezado a priori. Nem a tradição do método introspectivo, nem a herança da psiquiatria tradicional, nem as construções hipotéticas ou as construções práticas de inspiração psicanalítica, gestaltista ou behaviorista. De modo algum penso nos termos de um ecletismo estéril, mas numa revisão crítica e numa tentativa de invenção de um modelo adequado à psicologia, ao invés de continuar insistindo em se acomodar a modelos que não se aplicam a seu caso. E se for preciso em algum momento "imitar" algum modelo já existente, que se faça conforme a recomendação de $\operatorname{Kohler}(1948$, p. 50): imitemos inteligentemente.

Salvo melhor juízo, este é o meu parecer. 
Referências Bibliográficas

Alexander, F. e Selesnick, S. (1966) História da Psiquiatria. Trad. de Aydano Arruda. São Paulo, IBRASA. Altschule, M. D. (1976) The Development of Traditional Psychopathology. N. York, John Wiley \& Sons. Angell, J. R. (1907) "The Province of Functional Psychology". In: Psychological Review, XIV (2): 61-91, março de 1907.

Arnaldez, R. e Massignon, L. (1959) “A Ciência Árabe". In: Taton, R. e Outros -História Geral das Ciências, Tomo I, $3^{\circ}$ volume (A Ciência Antiga e Medieval), pp. 21-59. Trad. de R. Fausto e G. K. Ghinzberg. São Paulo, Difusão Européia do Livro.

Bakan, D. (1973) On Method. San Francisco, Jossey-Bass Publishers.

Bechterev, V. (1953) La psicologia objetiva. Trad. de L. G. Ratto e C. A. Duval. Buenos Aires, PAIDÓS.

Beloff, J. (1975) Psychological Sciences. London, Crosby Lockwood Staples.

Bernard, Claude (1963) Introduction à l'étude de la medicine expérimentale. Paris, Les Chefs-d'Oeuvre.

Bichat, X. (1859) Recherches physiologiques sur la vie et sur la mort. Paris, Charpentier.

Boring, E. G. (1957) The History of Experimental Psychology. New York, Appleton-Century-Crofts.

Brentano, F. (1944) Psychologie du point de vie empirique. Trad. de M. de Gandillac. Paris, Aubier.

Brett, G. S. (1963) Historia de la Psicologia. Trad. de D. An. Sampietro, Buenos Aires, PAIDÓS.

Burton, R. (1867) Anatomy of melancholy. London, William Yegg.

Cabanis, P. J. G. (1956) Deuvres philosophiques de Cabanis (T. XLIV). Trad. Paris, Presses Universitaires de France.

Canguilhem, G. (1960) "A Fisiologia Animal”. Em: Taton, R. e Outros: Ob. Cit. Tomo II, 3 ’ volume (A Ciência Moderna),, pp. 168-192. Caullery, N. (1957) "Les grandes étapes de la science biologique". Em: Daumas, M. Histoire de la Science. Paris, Gallimard.

Chertok, L. e Saussure, R. de (1973) Naissance du Psychanalyste — de Mesmer à Freud. Paris, Payot.

Darwin, Ch. (1872) The expression of emotions in man and animais. London, John Murray.

Daumas, M. (1957) Histoire de la Science. Paris, Gallimard.

Daumas, M. ( 1960) "A química dos princípios". Em: Taton, R. e Outros: Ob. Cit. Tomo II, 2 Vol. (A Ciência Moderna), pp. $190-206$.

Descartes, R. (1948) Deuvres philosophiques et morales. Paris, Bibliothèque des Lettres.

Descartes, R. (1952) Deuvres et Lettres. Paris, Gallimard.

Dulieu, L (1960) "A Medicina". Em: Taton, R. e Outros: Ob. Cit. Tomo II, Vol. 7 , pp. 9-30.

Dwelshauvers, G. (1930) Tratado de psicologia. Trad. de J. C. y Arteu. Barcelona, Gustavo Gilli.

Ebbinghaus, H. (1910) Précis de Psychologie. Trad. de G. Raphael. Paris, Alcan.

Flugel, J. C. (1953) A hundred years of Psychology. London, Gerald Duck-worth.

Foucault, M. (1974) Folie et déraison — Histoire de la folie à l'âge classique. Paris, Plon.

Foucault, M. (1977) O nascimento da clínica. Trad. de R. Machado. Rio de Janeiro, Forense Universitária.

Frobes, J. (1950) Tratado de Psicologia Empirica y Experimental. Trad. de J. A. Menchaca. Madrid, Razon y Fé.

Gall, F. J. (1822) Sur les fonctions du cerveau et sur celles de chacune de ses parties. Paris, Boucher, volume.

Gilbert, W. (1955) On the leadstone and Magnetic Bodiesand on the Great Magnet the Earth. Chicago, Encyclopaedia Britannica.

Gomes, P. (1973) Filosofia Grega Pré-Socrática. Lisboa, Guimarães \& Cia.

Gouhier, H. (1942) "Introduction" a Maine de Biran, Ob. Cit.

Groote, M. R. de (1967) La folie à travers les siècles. Paris, Robert Laffont.

Halda, B. (1970) Pour connaítre la pensée de Maine de Biran. Paris, Bordas.

Harvey, W. (1955) On the motion ot the heart and Blood in animais. On the circulation of the Blood. On the generation of Animais. Chicago, Encyclopaedia Britannica.

Heidbreder, E. (1933) Seven Psychologies. New York, D. Appleton-Century Co.

Hipócrates (1955) Hipocratic Writings. Chicago, Encyclopaedia Britannica.

Hoffding, H. (1909) Esquisse d'une psychologie fondée sur l'expérience. Trad. de L. Poítevin. Paris, Félix Alcan.

Horta Barbosa, L. H. (1963) História da Ciência. Rio de Janeiro, CNPq/IBBD.

James, W. (1955) The Principies of Psychology. Chicago, Encyclopaedia Britannica. 
Jolivet, R. (1947) Traité de Philosophie. T. II:Psychologie. Paris, Emmanuel Vitte, Éditeur.

Kohler, W. (1948) Psicologia de la forma. Trad. de E. Pucciarelli. Buenos Aires, Argonauta.

Koffka, K. (1953) Princípios de psicologia de la forma. Buenos Aires, Paidós.

Koffka, K. (1975) Princípios de psicologia da gestalt. Trad. de A. Cabral. São Paulo, Cultrix.

La Valette Monbrun (1914) Maine de Biran - essai de Biographie historique et psychologique. Paris, Fontemoing \& Cia.

Lavater, J. K. (1820) L'art de connaítre les hommes par la physionomie. Paris, Depélafol.

Lemoine, A. (1864) Le vitalisme et l'animisme de Stahl. Paris, Germer Baillière.

Levy, A. (1914) La vie et l'auvre médicale de Charles Le Pois: Carolus Piso. Nancy, Imprimeries Réuniesde Nancy.

Lian, G. (1945) A medicina árabe e sua influência na civilização européia. São Paulo, Cupulo.

Mach, E. (1906) La connaissance et l'erreur. Trad. de M. Dufour. Paris, Flammarion. Maine de Biran (1942) Oeuvres choisies. Paris, Aubier.

Marx, M. e Hillix, W. A. (1967) Sistemas y teorias psicológicos contemporáneos. Trad. de J. Calapionto. Buenos Aires, Paidós.

Mesmer, F. A. (1862) Memórias e aphorismos sobre o magnetismo animal. Trad. de E. A. Monteggia. Rio de Janeiro (não refere a editora):

Misiak, H. e Sexton, V. S. (1958) History of Psychology. New York, Grune \& Stratton.

Müeller, W. R. (1952) The anatomy of Robert Burton's England. Berkeley, University of California Press.

Murphy, G. (1960) Introducción histórica a la psicologia contemporánea. Trad. de E. Butelman. Buenos Aires, Paidós.

Nordenskiold, E. (1949) Evolución histórica de las ciencias biológicas. Trad. de J. Gorete. Buenos Aires, Espasa Calpe Argentina.

Noyes, A. P. e Kolbe, L. C. (1974) Psiquiatria Clínica Moderna. Trad. de L. C. Beltrán, México, La Prensa Médica Mexicana.

Pélicier, Y. (1973) História da Psiquiatria. Trad. de R. da Fonseca. Lisboa, Publicações Europa-América.

Pérez, J. A. S. (1954) La ciencia árabe en la edad média. Madrid, Instituto de Estúdios Africanos.

Piéron, H. (1958) De l'actinie à I'homme. Paris, Presses Universitaires de France.

Politzer, G. (1969) Crítica de los fundamentos de la psicologia. Trad. de F. Gallach. Barcelona, Martinez Rocca.

Politzer, G. (1973) Ecrits 2: Les fondements de la psychologie. Paris, Éditions Sociales.

Reuchlin, M. (1963) Histioire de la Psychologie. Paris, Presses Universitaires de France.

Ricoeur, P. (1969) Le conflit des interprétations. Paris, Éditions du Seuil.

Rubinstein, S. L. (1967) Princípios de Psicologia General. Trad. de S. Trowsky. México, Grijalbo.

Singer, (1934) Histoire de la biologie. Trad. de F. Giddon. Paris, Payot.

Sprenger e Kramer (1928) Malleus Maleficarum. London, The Hogarth Press.

Szasz, Th. (1974) La fabricación de la locura. Trad. de R. Ribé. Barcelona. Editorial Kairós.

Taylor, G. R. (1965) Histoire Illustrée de la Biologie. Texto em francês de C. Vendrely. Paris, Hachette.

Titchener, E. B. (1922) Manuel de Psychologie. Trad. de H. Lesage. Paris, Félix Alcan.

Tolman, E. C. (1951) Collected Papers in Psychology. Berkeley, University of California Press.

Varet, G. (1956) Manuel de bibliographie philosophique. Paris, Presses Universitaires de France.

Veith, I. (1973) Histoire de l'hystérie. Trad. de S. Dreyfus. Paris, Seghers.

Watson, J. B. (1913) “Psychology as the behaviorist vews it". Em: Psychological Review, 20, 158-177.

Watson, J. B. (1972) El conductismo. Trad. de O. Poli, Buenos Aires, Paidós.

Wertheimer, M. (1959) Productive Thinking. New York, Harper \& Row. Wolman, B. B. (1970) Teorias y Sistemas Contemporáneos em Psicologia. Barcelona, Martinez Rocca.

Woodworth, R. S. e Marquis, D. G. (1968) Psicologia. Trad. de L. C. Raymond. São Paulo, Companhia Editora Nacional. Wundt, W.

(1886) Eléments de Psychologie physiologique. 2 vols. Trad. de E. Rouvier. Paris, Félix Alcan.

Wundt, W. (1912) An Introduciton to Psychology. Trad. de R. Pintner. London, George Allen \& Co.

Ysabeau, A. (s. d.) Lavater et Gall. Paris, Garnier. 